\title{
Achieving sustained virologic response in hepatitis C: a systematic review of the clinical, economic and quality of life benefits
}

\author{
Jayne Smith-Palmer ${ }^{1 *}$, Karin Cerri ${ }^{2}$ and William Valentine ${ }^{1}$
}

\begin{abstract}
Background: The goal of chronic hepatitis $C$ treatment is to remove the virus to avoid progression of HCV-related disease. Sustained virologic response (SVR) is the most widely used efficacy endpoint in clinical studies of hepatitis C, and represents the eradication of HCV from the body. The aim of the current review was to examine the long-term clinical, economic and quality of life benefits associated with achieving SVR.
\end{abstract}

Methods: A systematic literature review was performed using the PubMed, EMBASE and Cochrane library databases to identify articles examining the clinical, economic and quality of life benefits associated with SVR, published in English language from 2002-2013. For inclusion studies were required to enroll $\geq 100$ patients and to report clinical endpoints including hepatocellular carcinoma, overall- or liver-related mortality, or progression of disease/complications (e.g. portal hypertension, esophageal varices). Review of economic studies on cost/cost-effectiveness of achieving SVR were focused on studies assessing boceprevir/telaprevir plus pegIFN and ribavirin as this represents the current standard of care in several jurisdictions worldwide. Quality of life evidence was required to use validated quality of life instruments and provide a quantitative analysis of the impact of SVR versus no treatment or treatment failure.

Results: SVR is durable with late relapse rates over $4-5$ year periods being in the range of $1-2 \%$. Patients who achieve SVR frequently demonstrate some regression of fibrosis/cirrhosis and have a substantially reduced risk for hepatocellular carcinoma (relative risk [RR] 0.1-0.25), liver-related mortality (RR 0.03-0.2) and overall mortality (RR 0.1-0.3) in comparison with no treatment or treatment failure. In the 5 years post-treatment, medical costs for patients achieving SVR are 13-fold lower than patients not achieving SVR. Patients who achieve SVR also have health state utility values that are 0.05 to 0.31 higher than non-responders to treatment.

Conclusions: SVR represents the fundamental goal of antiviral treatment for patients infected with chronic HCV, so as to reduce risk of liver disease progression. Achievement of SVR has implications beyond those of clearing viral infection; it is associated with improved long-term clinical outcomes, economic benefits and improved health-related quality of life.

Keywords: Sustained virologic response, Chronic hepatitis C, Cost, Quality of life, Utility, Morbidity, Mortality

\section{Background}

On a global level over $2 \%$ of the population are estimated to be infected with the hepatitis $\mathrm{C}$ virus $(\mathrm{HCV})$, which corresponds to a prevalent population of $>180$ million people with chronic infection [1]. For many patients who become chronically infected, HCV causes slow, progressive damage to the liver and represents one

\footnotetext{
* Correspondence: smith-palmer@ossianconsulting.com

'Ossian Health Economics and Communications, Ossian Health Economics and Communications GmbH, Bäumleingasse 20, 4051 Basel, Switzerland Full list of author information is available at the end of the article
}

of the leading causes of cirrhosis and hepatocellular carcinoma (HCC) [2]. Moreover, the slow insidious nature of disease progression means that many patients are unaware of their status until the later stages of disease.

Six major genotypes of $\mathrm{HCV}$ exist in many regions and the current standard of care for patients with $\mathrm{HCV}$ genotype 1 is therapy with a direct acting antiviral (DAA) in combination with ribavirin alone or combined with pegIFN or a combination of two DAAs (with or without ribavirin). The present study focuses on $\mathrm{HCV}$ genotype 1

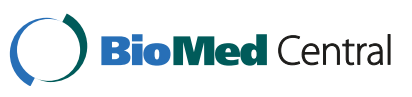


as this genotype occurs in all regions and is the predominant genotype in many regions.

The effectiveness of antiviral treatment, the extent to which treatment can clear viral infection is assessed according to the proportion of patients achieving sustained virologic response (SVR). SVR is the fundamental goal of treatment and is defined as undetectable (or below the lower limit of quantification) HCV RNA at 12-24 weeks after cessation of treatment [3,4]. SVR rates with a DAA in combination with pegIFN plus ribavirin (PR) currently range from approx. 80-90\% for treatment-naïve patients [5-8], whilst SVR rates of up to $99 \%$ have been reported with combinations of two DAAs [9]. Similarly, SVR rates of up to $99 \%$ have been reported in treatmentexperienced (non-responders and relapsers) patients treated with two-DAA combinations [10].

Although considered a surrogate endpoint (a biomarker indicative of viral clearance rather than a finite endpoint such as presence/absence of disease or mortality), SVR is widely accepted as the best available indicator of viral clearance and a subject with SVR is generally considered cured [11]. Rates of late relapse are extremely low and long-term (up to 4 years) studies of patients treated with pegIFN have shown that SVR is durable, with approximately $99 \%$ of patients remaining virus-free, although the patient is still at risk of subsequent reinfection [12].

To date, the vast majority of clinical trials in HCV, including phase III trials of boceprevir and telaprevir, have used SVR at 24 weeks after the planned end of treatment (SVR24) as the primary endpoint. However, research in the field of HCV is currently advancing at a rapid pace and SVR 12 weeks after the end of treatment is now used as the primary endpoint in most clinical studies. The concordance between SVR12 and SVR24 rates has been investigated, and a high level of concordance was observed, suggesting that SVR12 represents a valid clinical endpoint $[13,14]$. Specifically, analysis was performed by the FDA in which data from fifteen Phase 2 and 3 trials $(n=12,000$ patients) were combined to assess the concordance between SVR24 and SVR12. This analysis showed that concordance was observed between SVR12 and SVR24 for all treatments: $98 \%$ of patients with SVR212 had SVR24 [15].

As mentioned, SVR is the most commonly used endpoint in clinical trials in hepatitis $C$ because the use of incidence of HCC or liver-related mortality as an endpoint is impractical within the context of a clinical trial. Patients with SVR following 24-48 weeks of treatment are generally considered to be permanently cured. While long-term follow-up is still required to fully assess the impact of SVR on hard clinical endpoints such as the progression to compensated or decompensated cirrhosis, HCC and liver-related mortality, it has been shown that patients who achieve SVR have a considerably reduced incidence of liver-related complications in comparison with those who fail treatment. As well as clinical implications, SVR rates can be anticipated to have an impact on the economic burden and humanistic burden of disease. HCV-related complications, such as HCC or livertransplantation are associated with high direct medical costs and high levels of healthcare resource utilization [16], therefore any reduction in the incidence of HCVrelated complications may have a considerable long-term economic benefit. This also extends to work productivity, as patients with SVR have higher post-treatment employment rates than those who fail treatment $[17,18]$. However, in the short-term improvements in SVR rates may be associated with increased pharmacy costs; for example, in an analysis in the French setting Deuffic-Burban et al. projected that the introduction of triple therapy would lead to a 3-4 fold increase in the number of genotype 1 patients receiving treatment at a cost of EUR 497-638 million [19]. As HCV is a transmissible disease, from a public health perspective, benefits of improved SVR rates include a reduced prevalent population and therefore the potential for lower transmission and incidence rates.

The objectives of the current study were to perform a literature review to understand the link between the clinical implications of achievement of SVR with the economic and patient quality of life implications by, firstly, exploring the clinical validity of SVR as an endpoint in terms of the impact of SVR on the incidence of liver-related complications including mortality and HCC and secondly, to assess the impact of attainment of SVR in terms of long-term economic outcomes and quality of life in patients infected with chronic $\mathrm{HCV}$ infection.

\section{Methods}

The search strategy for the literature review was designed using high level Medical Subject Heading (MeSH) terms and supplemented with free text terms and adapted for the PubMed, EMBASE and Cochrane Library databases as required; all initial searches were run on 08 January 2013 (subsequent searches with the same search terms were run on 29 April 2014 to capture studies published since the initial review was performed). For the PubMed searches, MeSH terms used included Hepatitis C [MeSH] OR Hepacivirus [MeSH]; free-text terms were used to identify articles focusing on sustained virologic response (wildcards were used to capture variations in terminology). For the EMBASE searches, MeSH terms were mapped to EMBASE equivalents using the "map term" functionality.

The review was limited to articles published in the last 10 years and for inclusion, studies were required to be published in English and have a minimum enrollment of 100 patients (Table 1) (a minimum cohort size of 100 patients was chosen to focus on relatively large scale studies 
Table 1 Summary of inclusion and exclusion criteria applied in the literature review

\begin{tabular}{ll}
\hline Inclusion criteria & Exclusion criteria \\
\hline All studies & All studies \\
Published 2003-2014 & Conducted exclusively in HIV co-infected patients \\
Published in English & Conducted exclusively in pediatric patients \\
Conducted in patients with chronic HCV & Wrong publication type: letters, case studies, editorials and commentaries were excluded \\
& Conducted exclusively in patients with genotypes 2, 3, 4, 5 or 6 \\
Clinical studies & Clinical studies \\
Minimum 1 year post-treatment follow-up & $<100$ patients \\
Report hard clinical endpoints (e.g. overall mortality, & Endpoints limited to biochemical parameters only (e.g. aminotransferase levels only)
\end{tabular}
incidence of hepatocellular carcinoma)

\section{Health economic studies}

Assessing cost-effectiveness of protease inhibitors versus pegIFN plus ribavirin, pegIFN, IFN or no treatment

\section{Quality of life studies}

Presentation of quantitative results using a validated quality of life instrument

\section{Health economic studies}

Assessing pegIFN plus ribavirin versus pegIFN, IFN or no treatment

Quality of life studies

$\mathrm{HCV}$, hepatitis C virus; HIV; human immunodeficiency virus; pegIFN, pegylated interferon; IFN, interferon.

that could detect relatively small differences in outcomes and to preclude small scale pilot studies conducted in highly selective patient populations). The focus of the review was on patients with $\mathrm{HCV}$ genotype 1 , and studies exclusively in patients with HCV genotypes 2 and 3, or in patients with HIV coinfection, were excluded. Clinical studies were also required to have a minimum follow up of 1-year post-cessation of treatment, compare outcomes in patients with SVR versus either untreated patients or those failing to achieve SVR, and report hard clinical endpoints; studies reporting biochemical parameters only, such as alanine amino transferase levels, were excluded. Cost-effectiveness studies were also limited to studies incorporating analyses of protease inhibitor-based triple therapy regimens; studies evaluating pegIFN plus ribavirin in comparison with pegIFN or IFN alone or no treatment were excluded. Studies reporting on health-related quality of life evidence were required to use validated quality of life instruments and provide a quantitative analysis of the impact of SVR versus no treatment or treatment failure.

The literature searches across the three databases identified a total of 4,206 unique hits after two rounds of screening (first round screening by title and abstract only and second round full-text screening of short-listed articles.) A total of 44 clinical studies (including 4 metaanalyses), 15 quality of life studies (one additional quality of life was identified in supplementary hand searches) and 2 economic studies were included in the final analysis (Figure 1). The review was performed in line with PRISMA guidance and a schematic diagram of the literature review process is shown in the Additional file 1. Updated searches performed in April 2014 identified an additional 20 clinical studies and 3 cost/cost-effectiveness studies.

\section{Results}

\section{Clinical benefits}

The literature review process identified a large number of studies that examined the impact of SVR on the longterm risk of a number of clinical outcomes including incidence of HCC, liver transplantation, liver-related mortality and overall mortality in populations with differing levels of severity. Data were captured from a large range of patient populations in terms of relative prevalence of different HCV genotypes, severity of liver disease at baseline and treatment type.

\section{Hepatocellular carcinoma}

On a global level, HCV is one of the leading causes of $\mathrm{HCC}$, and is typically associated with a poor prognosis. A total of 34 studies [20-48] including five meta-analyses [49-53] that examined the impact of SVR on risk of HCC were identified (Table 2). The overwhelming consensus of the results of the studies included was that patients who achieve SVR have a considerably reduced risk for HCC in comparison with untreated patients or those who fail to achieve SVR. However, the magnitude of this effect varied, with reported RRs for HCC in patients with SVR versus non-responders or untreated patients ranging from 0.09-0.35.

The 2010 meta-analysis by Singal et al. showed that patients who had SVR (following treatment with IFN alone or IFN plus ribavirin) had a RR (95\% CI) for HCC of $0.35(0.26-0.46)$ in comparison with non-responders [49]. Similarly, the meta-analysis by Kimer et al. reported a RR (95\% CI) for HCC of 0.15 (0.05-0.45); however, the comparator group was untreated patients, rather than non-responders to therapy [51]. Notably, the analysis by Singal et al. included only studies in patients with 


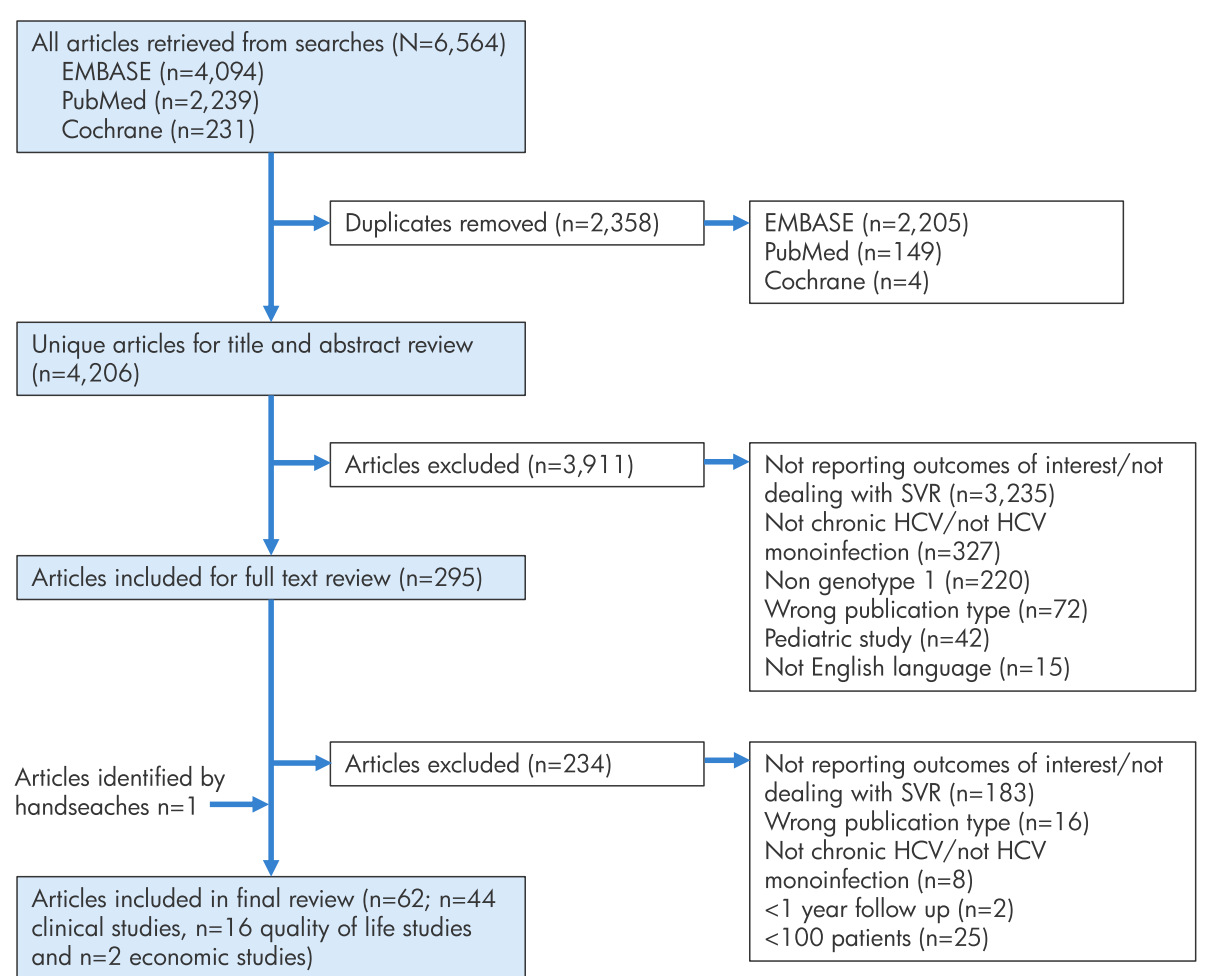

Figure 1 Diagram of literature review process. Note: the original literature searches were re-run in April 2014 to capture publications published since the original searches. A total of twenty additional clinical articles and three additional economic studies were identified.

cirrhosis, whereas the analysis by Kimer et al. included two studies in mixed or non-cirrhotic patients.

Studies examining the impact of SVR on risk for HCC in Japan are of particular interest owing to the high relative prevalence of HCV genotype $1 \mathrm{~b}$, (which is associated with a higher incidence of HCC than genotype 1a) and high incidence of $\mathrm{HCV}$-associated $\mathrm{HCC}$ in this setting. For $\mathrm{HCV}$ patients with cirrhosis the annual probability of $\mathrm{HCC}$ is $1-4 \%$, although this increases to $5-8 \%$ for patients with HCV genotype 1b [54,55]. Japan-based studies also showed that SVR was associated with reduced risk for HCC versus non-response, although as expected the absolute risk in both SVR and non-SVR population was increased with advanced age and increased severity of fibrosis. For example, Yoshida et al. determined SVRrelated gain in HCC-free survival as both a function of age and fibrosis level (as measured by METAVIR F0-F4) [36]. For male patients with F0/F1 stage disease the gain in HCC-free survival with SVR was 2.48 years for patients aged 30 years, reducing to 0.15 years for patients aged 80 years. For patients with F4 stage disease SVR-induced gain in HCC free survival was 15.98 years at age 30 years, but only 2.38 years at age 80 years [36]. In another Japanese study by Imazeki et al., in the overall treated $\mathrm{HCV}$ population they report an annual HCC incidence of $0.5 \%$ for those with SVR versus $2.6 \%$; whereas in patients with cirrhosis, the corresponding figures were $1.4 \%$ and
$5.9 \%$, respectively [46]. Similar findings were reported in other studies in the Japanese setting [22,24,29]. Only two studies (out of thirteen) from the Japanese setting reported no difference in the incidence of HCC for patients achieving SVR versus those without SVR [34].

\section{Liver-related mortality}

Analysis of clinical studies also showed that patients who achieve SVR have a substantially lower risk of liver-related mortality and overall mortality than non-responders to treatment, irrespective of genotype, setting or disease severity level, with a considerable proportion of studies showing that this reduction in risk was statistically significant (Table 3). In individual studies the RR for overall mortality for patients with SVR versus non-response or no treatment ranged from $0.14-0.70$, whilst the corresponding figures for liver-related mortality were $0.03-0.22$. As with HCC studies, the magnitude of the effect of SVR on mortality risk varied considerably between studies, which may be attributable in part to differences in patient characteristics such as mean age and disease stage prior to treatment. A 2010 meta-analysis reported a RR (95\% CI) for liver-related mortality of $0.23(0.10-0.52)$ for SVR patients compared with treatment failures, although if only patients with advanced fibrosis/cirrhosis were included this figure decreased to $0.13(0.06-0.29)$ [50]. These findings were echoed in individual studies. For example, a 
Table 2 Summary of clinical studies reporting the impact of SVR on HCC

\begin{tabular}{|c|c|c|c|c|c|}
\hline Study & Setting & $\begin{array}{l}\text { Sample } \\
\text { size }\end{array}$ & $\begin{array}{l}\text { Mean } \\
\text { follow up }\end{array}$ & Study details & Key findings \\
\hline $\begin{array}{l}\text { Coverdale et al. } \\
2004 \text { [47] }\end{array}$ & Australia & 455 & 9 years $^{\mathrm{a}}$ & $\begin{array}{l}\text { Retrospective cohort study including } \\
384 \text { treated with IFN alone, }(n=71 \\
\text { untreated) including patients with cirrhosis }\end{array}$ & $\begin{array}{l}\text { Overall 9-year incidence of HCC was 10\% } \\
\text { for untreated, } 11 \% \text { for non-response and } \\
2 \% \text { for SVR }\end{array}$ \\
\hline $\begin{array}{l}\text { Van der Meer } \\
\text { et al. } 2013 \text { [20] }\end{array}$ & $\begin{array}{l}\text { Europe and } \\
\text { Canada }\end{array}$ & 248 & 8.3 years $^{a}$ & $\begin{array}{l}\text { Cohort of consecutive genotype } 1 \text { patients } \\
\text { with advanced fibrosis, } 24 \% \text { with SVR }\end{array}$ & $\begin{array}{l}\text { HR }(95 \% \mathrm{Cl}) \text { for HCC for SVR versus non-SVR } \\
\text { was } 0.20(0.06-0.69)(p=0.011)\end{array}$ \\
\hline $\begin{array}{l}\text { Van der Meer } \\
\text { et al. } 2012 \text { [38] }\end{array}$ & $\begin{array}{l}\text { Europe and } \\
\text { Canada }\end{array}$ & 530 & 8.4 years $^{\mathrm{a}}$ & $\begin{array}{l}\text { Retrospective cohort study in patients with } \\
\text { advanced fibrosis/cirrhosis treated with IFN, } \\
\text { IFN plus ribavirin or pegIFN plus ribavirin, } \\
\text { median follow up } 8.4 \text { years, } 68 \% \text { genotype } 1\end{array}$ & $\begin{array}{l}\text { Rate (per } 100 \text { patient years) for HCC were } \\
0.55(0.14-0.96) \text { for SVR Vs. } 2.63(1.83-3.82) \\
\text { without SVR ( }<0.001)\end{array}$ \\
\hline $\begin{array}{l}\text { Braks et al. } \\
2007[43]\end{array}$ & France & 113 & $8.2(3.1)$ years & $\begin{array}{l}\text { Retrospective cohort study in patients with } \\
\text { compensated cirrhosis treated with IFN or } \\
\text { pegIFN-based treatment }\end{array}$ & $\begin{array}{l}\text { Proportion of patients with HCC was } 2.7 \% \\
\text { for SVR versus } 31.6 \% \text { for non-SVR }\end{array}$ \\
\hline $\begin{array}{l}\text { Cardoso et al. } \\
2010 \text { [42] }\end{array}$ & France & 307 & 3.5 years $^{a}$ & $\begin{array}{l}\text { Retrospective analysis in patients with } \\
\text { bridging fibrosis or cirrhosis treated } \\
\text { with IFN, pegIFN or pegIFN plus ribavirin }\end{array}$ & $\begin{array}{l}\text { Adjusted HR }(95 \% \mathrm{Cl}) \text { for non-SVR versus } \\
\text { SVR was } 3.06(1.12-8.39)(p=0.029) \text { for HCC }\end{array}$ \\
\hline $\begin{array}{l}\text { Bruno et al. } \\
2007[44]\end{array}$ & Italy & 883 & 96.1 months & $\begin{array}{l}\text { Retrospective database analysis in patients } \\
\text { treated with IFN monotherapy with no }\end{array}$ & $\begin{array}{l}\text { Adjusted HR }(95 \% \mathrm{Cl}) \text { for non-SVR versus } \\
\text { SVR was } 2.59(1.13-5.97)(p=0.025) \text { for HCC }\end{array}$ \\
\hline
\end{tabular}

\begin{tabular}{|c|c|c|c|c|}
\hline $\begin{array}{l}\text { Calvaruso et al. } \\
2013 \text { [23] }\end{array}$ & Italy & 444 & $\begin{array}{l}69 \text { months }^{a} \\
\text { (range 24-130 } \\
\text { months) }\end{array}$ & $\begin{array}{l}\text { Prospective cohort study in PR-treated } \\
\text { patients with compensated cirrhosis, } \\
83 \% \text { genotype 1, } 24 \% \text { with SVR }\end{array}$ \\
\hline $\begin{array}{l}\text { Pellicelli et al. } \\
2013 \text { [27] }\end{array}$ & Italy & 172 & 5 years $^{\mathrm{a}}$ & $\begin{array}{l}\text { Retrospective-prospective study in } \\
\text { patients with HCV genotype } 1 \text { treated } \\
\text { with pegIFN plus ribavirin, } 34 \% \text { with } \\
\text { cirrhosis }\end{array}$ \\
\hline $\begin{array}{l}\text { Hara et al. } \\
2014 \text { [24] }\end{array}$ & Japan & 1,125 & Not stated & $\begin{array}{l}\text { Retrospective cohort study in PR-treated } \\
\text { (SVR and non SVR) and untreated patients }\end{array}$ \\
\hline $\begin{array}{l}\text { Ikeda et al. } \\
2006 \text { [35] }\end{array}$ & Japan & 2,166 & 15 years & $\begin{array}{l}\text { Retrospective cohort study in patients with } \\
\text { HCV patients ( } n=512 \text { untreated, } n=1,654 \\
\text { treated with IFN-based therapy) }\end{array}$ \\
\hline $\begin{array}{l}\text { Imai et al. } \\
2010 \text { [28] }\end{array}$ & Japan & 568 & 11 years & $\begin{array}{l}\text { Retrospective cohort study in consecutive } \\
\text { HCV patients treated with IFN monotherapy }\end{array}$ \\
\hline
\end{tabular}

Imazeki et al. Japan $\quad 459 \quad 8.9$ (3.2) years Retrospective cohort study in patients, inc 2005 [46] patients with cirrhosis, treated with IFN alone $(n=355)$ or untreated $(n=104)$, $\mathrm{n}=116$ patients achieved SVR

Kobayashi et al. Japan

1,124 66 months $^{\mathrm{a}} \quad$ Retrospective cohort study in HCV patients 2007 [29] (range 12-197 treated with IFN or IFN plus ribavirin months) (373 with SVR, 751 without SVR)

Maruoka et al. Japan 2012 [40]

$\begin{array}{lll}\begin{array}{l}\text { Moriyama et al. Japan } \\ 2005[31]\end{array} & 269 & >6 \text { years } \\ \text { Ogawa et al. Japan } & 1,013 \quad 3.6 \text { years }^{\mathrm{a}}\end{array}$
2013 [25]
$721 \quad 9.9(5.3)$ years

Retrospective cohort study in patients treated with monotherapy $(n=577$, of which $n=221$ (38.3\%) achieved SVR and $\mathrm{n}=144$ untreated patients

Retrospective study in patients with cirrhosis treated with IFN-based treatment

Prospective multicenter study in patients treated with pegIFN plus ribavirin, $70.1 \%$ had HCV genotype 1 and $14.8 \%$ had cirrhosis at baseline
HR (95\% Cl) for HCC for non SVR versus $S V R=4.44(1.30-15.11)(p=0.017)$

Multivariate OR (95\% CI) for development of HCC for no SVR versus SVR $=3.58$ $(0.9-14.3)(p=0.06)$

HR $(95 \% \mathrm{Cl})$ for HCC for SVR versus non-SVR and untreated $=0.12(0.03-0.48)(p=0.003)$

Crude rate of HCC at 15 years was $13.9 \%$ for all treated patients, 23.9\% for untreated and $7.5 \%$ for SVR

HR $(95 \%$ Cl) for HCC for SVR versus non-treated patients was $0.20(0.08-0.50)$ $(p<0.001)$ for patients $<60$ years and $0.23(0.08-0.64)(p=0.005)$ for patients $>60$ years

In the total population, annual incidence of HCC was $0.5 \%$ for SVR versus $2.6 \%$ for non-responders; corresponding figures for patients with cirrhosis were 9\% and 34\%, respectively

HCC developed in 3.5\% SVR patients versus $8.1 \%$ non-SVR patients. SVR HCC patients had a significantly more advanced stage of fibrosis $(p<0.001)$

Annual rate of HCC development was 2.71\% for untreated patients, $2.31 \%$ for non-SVR and $0.24 \%$ for SVR $(p<0.0001)$

Mean annual incidence of HCC was $0.78 \%$ for SVR versus $0.17 \%$ for non-responders with ALT $<80 \mathrm{IU}$ and $4.68 \%$ for ALT $>80 \mathrm{IU}$

HR $(95 \%$ Cl) for HCC relative to SVR $=1.50$ $(0.65-3.44)(p=0.34)$ for relapse and breakthrough and $3.72(1.69-8.18)(p=0.001)$ for non-response 
Table 2 Summary of clinical studies reporting the impact of SVR on HCC (Continued)

\begin{tabular}{|c|c|c|c|c|c|}
\hline $\begin{array}{l}\text { Ogawa et al. } \\
2012[37]\end{array}$ & Japan & 1,015 & $\begin{array}{l}3.8 \text { years } \\
(2-6 \text { years })\end{array}$ & $\begin{array}{l}\text { Prospective multicenter study in patients } \\
\text { treated with peglFN plus ribavirin } \\
(n=712 \text { genotype } 1, n=303 \text { genotype } 2 \text { ) }\end{array}$ & $\begin{array}{l}\text { 6-year cumulative incidence of HCC was } \\
3.4 \% \text { for SVR versus } 21.2 \% \text { for non-response } \\
\text { group ( } p<0.0001 \text { ) and } 6.4 \% \text { for transient } \\
\text { response (ns) }\end{array}$ \\
\hline $\begin{array}{l}\text { Sasaki et al. } \\
2014 \text { [22] }\end{array}$ & Japan & 916 & Not stated & Retrospective study of IFN-treated patients & $\begin{array}{l}\text { Incidence of HCC was } 3.6 \% \text { in patients } \\
\text { who achieved SVR vs. } 21.2 \% \text { in non-SVR } \\
\text { patients }\end{array}$ \\
\hline $\begin{array}{l}\text { Sasaki et al. } \\
2011[34]\end{array}$ & Japan & 236 & 50 months $^{a}$ & $\begin{array}{l}\mathrm{N}=236 \text { patients with IFN-based treatment, } \\
\text { median follow up } 50 \text { months }\end{array}$ & $\begin{array}{l}\text { No significant difference in incidence of } \\
\text { HCC for SVR versus non-SVR }\end{array}$ \\
\hline $\begin{array}{l}\text { Watanabe } \\
\text { et al. } 2011 \text { [32] }\end{array}$ & Japan & 1,865 & 4.25 years $^{\mathrm{a}}$ & $\begin{array}{l}\text { Retrospective cohort study in patients } \\
\text { treated with pegIFN plus ribavirin, } n=999 \\
(54 \%) \text { with SVR }\end{array}$ & $\begin{array}{l}5 \text { year cumulative incidence of HCC was } \\
1.1 \% \text { in patients with SVR and } 7.1 \% \text { in } \\
\text { non-SVR patients }(p<0.001)\end{array}$ \\
\hline $\begin{array}{l}\text { Yoshida et al. } \\
2004[36]\end{array}$ & Japan & 2,787 & $>6.5$ years $^{\mathrm{a}}$ & $\begin{array}{l}\text { Retrospective database analysis in HCV } \\
\text { patients ( } n=395 \text { untreated, } n=836 \text { SVR, } \\
\text { and } n=1,556 \text { non-SVR) }\end{array}$ & $\begin{array}{l}\text { HR }(95 \% \mathrm{Cl}) \text { for } \mathrm{HCC} \text { for non-SVR versus } \\
\text { no treatment was } 0.835(0.625-1.125) \\
\text { ( } p=\text { ns). }\end{array}$ \\
\hline $\begin{array}{l}\text { Velosa et al. } \\
2011 \text { [39] }\end{array}$ & Portugal & 130 & $6.4(4.0)$ years & $\begin{array}{l}\text { Retrospective cohort study in patients } \\
\text { with cirrhosis treated with IFN, IFN plus } \\
\text { ribavirin or pegIFN plus ribavirin }\end{array}$ & $\begin{array}{l}\text { HR }(95 \% \mathrm{Cl}) \text { for HCC for SVR versus } \\
\text { non-SVR was } 0.09(0.01-0.77)(p=0.024)\end{array}$ \\
\hline $\begin{array}{l}\text { Aleman et al. } \\
2013[26]\end{array}$ & Sweden & 351 & 5.3 years & $\begin{array}{l}\text { Prospective multicenter study in patients } \\
\text { with HCV-related cirrhosis treated with } \\
\text { pegIFN plus ribavirin, } 50 \% \text { genotype } 1\end{array}$ & $\begin{array}{l}\text { HR }(95 \% C l) \text { for HCC for SVR versus } \\
\text { non-SVR }=0.38(0.14-0.88)(p=0.04)\end{array}$ \\
\hline $\begin{array}{l}\text { Hung et al. } \\
2006 \text { [30] }\end{array}$ & Taiwan & 132 & $\begin{array}{l}37 \text { months }^{\mathrm{a}} \\
(12-63 \\
\text { months })\end{array}$ & $\begin{array}{l}\text { Retrospective cohort study in HCV patients } \\
\text { with cirrhosis, inc. patients with HBV or HIV } \\
\text { coinfection, } 56 \% \text { genotype } 1 \mathrm{~b} \text {, treated with } \\
\text { pegIFN plus ribavirin }\end{array}$ & $\begin{array}{l}4 \text { year cumulative incidence of HCC } \\
\text { was } 28 \% \text { in non-SVR versus } 8 \% \text { in SVR } \\
\text { group ( } p=0.0178)\end{array}$ \\
\hline $\begin{array}{l}\text { Wang et al. } \\
2011 \text { [33] }\end{array}$ & Taiwan & 164 & 8 years & $\begin{array}{l}\text { Retrospective cohort study in patients } \\
\text { treated with pegIFN plus ribavirin }\end{array}$ & $\begin{array}{l}\text { Incidence of HCC was } 8.8 \% \text { for patients } \\
\text { with an SVR versus } 14.3 \% \text { for untreated } \\
\text { patients ( } p=0.352)\end{array}$ \\
\hline $\begin{array}{l}\text { Yu et al. } \\
2006[45]\end{array}$ & Taiwan & 1,619 & 5.2 years & $\begin{array}{l}\text { Prospective study in patients with or } \\
\text { without cirrhosis ( } n=562 \text { untreated and } \\
n=1,057 \text { treated with IFN or IFN } \\
\text { plus ribavirin) }\end{array}$ & $\begin{array}{l}\text { RR }(95 \% \mathrm{Cl}) \text { for HCC versus untreated } \\
\text { was } 0.245(0.13-0.46)(p<0.0001) \text { for SVR } \\
\text { and } 0.990(0.635-1.541)(p=0.963) \\
\text { for non-SVR }\end{array}$ \\
\hline $\begin{array}{l}\text { Morgan et al. } \\
2010 \text { [41] }\end{array}$ & $\begin{array}{l}\text { United } \\
\text { States }\end{array}$ & 140 & $\begin{array}{l}78.6(15.9) \\
\text { months }\end{array}$ & $\begin{array}{l}\text { Prospective analysis from the HALT-C trial } \\
\text { in patients with advanced fibrosis treated } \\
\text { with pegIFN plus ribavirin and achieving SVR }\end{array}$ & $\begin{array}{l}\text { HR }(95 \% \text { CI) for SVR versus non response } \\
\text { was } 0.19(0.04-0.80) \text { for HCC }\end{array}$ \\
\hline $\begin{array}{l}\text { Wang et al. } \\
2013 \text { [21] }\end{array}$ & Not stated & 138 & 8 years & $\begin{array}{l}\text { Patients (mean age } 56 \text { years) treated with } \\
\text { PR, } 80 \% \text { achieved SVR }\end{array}$ & $\begin{array}{l}\text { 8-year incidence of HCC was } 13.5 \% \text { for } \\
\text { SVR patients, } 23.5 \% \text { for relapsers and } 20 \% \\
\text { for non-responders ( } p=0.518 \text { ) }\end{array}$ \\
\hline
\end{tabular}

${ }^{a}$ Median follow up.

ALT, alanine aminotransferase; $\mathrm{Cl}$, confidence interval; HCC, hepatocellular carcinoma; HR, hazard ratio; IFN, interferon; ns, not significant; SVR, sustained virologic response.

large scale ( $\mathrm{N}=1,215$ treatment-naïve patients), UK-based retrospective study reported a multivariate $\mathrm{HR}(95 \% \mathrm{CI})$ for liver-related death for SVR patients of $0.22(0.09-0.58)$ $(\mathrm{p}<0.01)$ [56]. Similarly, an Italian study of HCV patients (with no cirrhosis) reported that not achieving SVR (versus SVR) increased the HR (95\% CI) for liver-related death to 6.97 (1.70-28.42) [44]. Additionally, studies in the Japanese setting reported similar findings, with two studies reporting RRs for liver-related mortality of 0.03-0.04 for patients achieving SVR versus untreated patients $[57,58]$.

The benefits of SVR in terms of reduced risk for liverrelated mortality were apparent regardless of baseline severity. A multicenter study by van der Meer et al. [38] with over 8 years of follow up was conducted exclusively in patients with advanced fibrosis or cirrhosis at baseline. 
Table 3 Summary of clinical studies reporting the impact of SVR on all-cause and liver-related mortality

\begin{tabular}{lllll}
\hline Study & Setting & $\begin{array}{l}\text { Sample } \\
\text { size }\end{array}$ & $\begin{array}{l}\text { Mean } \\
\text { follow up }\end{array}$ & Study details \\
\hline $\begin{array}{l}\text { Selzner et al. } \\
2009 \text { [59] }\end{array}$ & Canada & 446 & 68 months $^{\text {a }}$ & $\begin{array}{l}\text { Retrospective cohort study } \\
\text { in liver transplant recipients } \\
\text { treated with IFN-based therapy }\end{array}$ \\
$\begin{array}{l}\text { Tanaka et al. } \\
2013 \text { [60] }\end{array}$ & Canada & 245 & 5.7 years & $\begin{array}{l}\text { Retrospective single center study } \\
\text { in liver transplant recipients } \\
\text { undergoing treatment } \\
\text { (agents not stated) }\end{array}$ \\
& & & &
\end{tabular}

\section{Outcomes Key findings}

assessed

\author{
Overall survival Actuarial 5-year survival rates \\ were $96 \%$ for SVR and 69\% for \\ non-response $(p<0.0001)$ \\ All cause \\ mortality \\ HR for all cause mortality for SVR \\ versus non-response $=0.091$ \\ (0.04-0.21) ( $p<0.001)$. HR for all \\ cause mortality for relapse versus \\ non-response $=0.19(0.06-0.63)$ \\ $(p=0.006)$

\section{All cause $\quad H R$ for all cause mortality for mortality SVR versus non-SVR was $0.25-0.26(p<0.001)$}

$\begin{array}{ll}\text { Van der Meer } & \text { Europe and } 530 \quad 8.4 \text { years } \\ \text { et al. 2012 [38] } & \text { Canada }\end{array}$

Retrospective cohort study in patients with advanced fibrosis/cirrhosis treated with IFN, IFN plus ribavirin or pegIFN plus ribavirin, 68\% genotype 1

$\begin{array}{lll}\text { Van der Meer } & \text { Europe and } 248 & 8.3 \text { years } \\ \text { et al. } 2012[61] & \text { Canada } & \end{array}$

Retrospective cohort study in patients with HCV genotype 1 with cirrhosis, treated with IFN-based treatment, 88\% treatment-naïve at baseline

Aguilera et al. France $114 \quad$ Not stated 2012 [62]

France

114

liver transplant recipients treated with pegIFN plus ribavirin

$\begin{array}{llll}\text { Cardoso et al. } & \text { France } & 307 & 3.5 \text { years }^{\text {a }} \\ 2010 \text { [42] } & & & \\ & & & \\ \text { Kutala et al. } & \text { France } & 484 & 4.5 \text { years }^{\text {a }} \\ 2013 \text { [63] } & & & \end{array}$

\begin{tabular}{|c|c|c|c|c|}
\hline $\begin{array}{l}\text { Bruno et al. } \\
2007 \text { [44] }\end{array}$ & Italy & 883 & 96.1 months & $\begin{array}{l}\text { Retrospective database analysis } \\
\text { in patients treated with IFN } \\
\text { monotherapy with no cirrhosis } \\
\text { or decompensation, } 73.5 \% \\
\text { genotype } 1\end{array}$ \\
\hline $\begin{array}{l}\text { Calvaruso et al. } \\
2013 \text { [23] }\end{array}$ & Italy & 444 & $\begin{array}{l}69 \text { months }^{a} \\
\text { (range 24-130 } \\
\text { months) }\end{array}$ & $\begin{array}{l}\text { Prospective cohort study in } \\
\text { PR-treated patients with } \\
\text { compensated cirrhosis, } \\
83 \% \text { genotype 1, } 24 \% \\
\text { with SVR }\end{array}$ \\
\hline $\begin{array}{l}\text { Hara et al. } \\
2014 \text { [24] }\end{array}$ & Japan & 1,125 & Not stated & $\begin{array}{l}\text { Retrospective cohort study } \\
\text { in PR-treated (SVR and non SVR) } \\
\text { and untreated patients }\end{array}$ \\
\hline $\begin{array}{l}\text { Imazeki et al. } \\
2003 \text { [58] }\end{array}$ & Japan & 459 & $8.2(2.9)$ years & $\begin{array}{l}\text { Retrospective cohort study in } \\
\text { consecutive patients with } \mathrm{CHC} \\
\text { (335 treated with IFN and } \\
104 \text { untreated) }\end{array}$ \\
\hline
\end{tabular}

Retrospective analysis in patients with bridging fibrosis or cirrhosis treated with IFN, pegIFN or pegIFN plus ribavirin

Retrospective study in patients with advanced fibrosis, SVR rate was $30 \%$ in treated patients

04 untreated)

\section{All cause Unadjusted HR (95\% Cl) for all mortality cause mortality for SVR 0.20 $(0.06-0.64)(p=0.007)$}

Overall survival For patients with F0-F1, 10 year survival was $100 \%$ for SVR versus $76 \%$ for non-response $(p=0.024)$. For patients with F3-F4, 7-year survival was $85 \%$ for SVR versus

Liver-related Adjusted HR (95\% Cl) for mortality non-SVR versus SVR was 3.71 (1.05-13.05) ( $p=0.041)$ for liver-related mortality

All cause mortality

5 year survival rate was 100\% in those with SVR vs. 54\% for those without SVR ( $p<0.0001), H R$ (95\% CI) for mortality for non-SVR versus SVR was 6.8 (2.5-20.5)

Liver-related Adjusted HR (95\% Cl) for non-SVR mortality versus SVR was 6.97 (1.70-28.42) $(p=0.0007)$ for liver-related mortality

Liver-related mortality

HR (95\% Cl) for liver related death for no SVR versus SVR $=6.56$ $(2.06-20.92)(p=0.001)$

All cause mortality

HR $(95 \% \mathrm{Cl})$ for all cause mortality for SVR vs non-SVR and untreated $=0.08(0.01-0.55)$ $(p=0.011)$

All-cause mortality, liver-related mortality $72 \%$ for non-response ( $p=n s$ )
Adjusted RR (95\%Cl) for all cause mortality for SVR versus untreated was $0.22(0.07-0.71)(p=0.0114)$.

Adjusted RR ( $95 \%$ Cl) for liver-related death was 0.03 $(0.003-0.28)(p=0.0017)$ 
Table 3 Summary of clinical studies reporting the impact of SVR on all-cause and liver-related mortality (Continued)

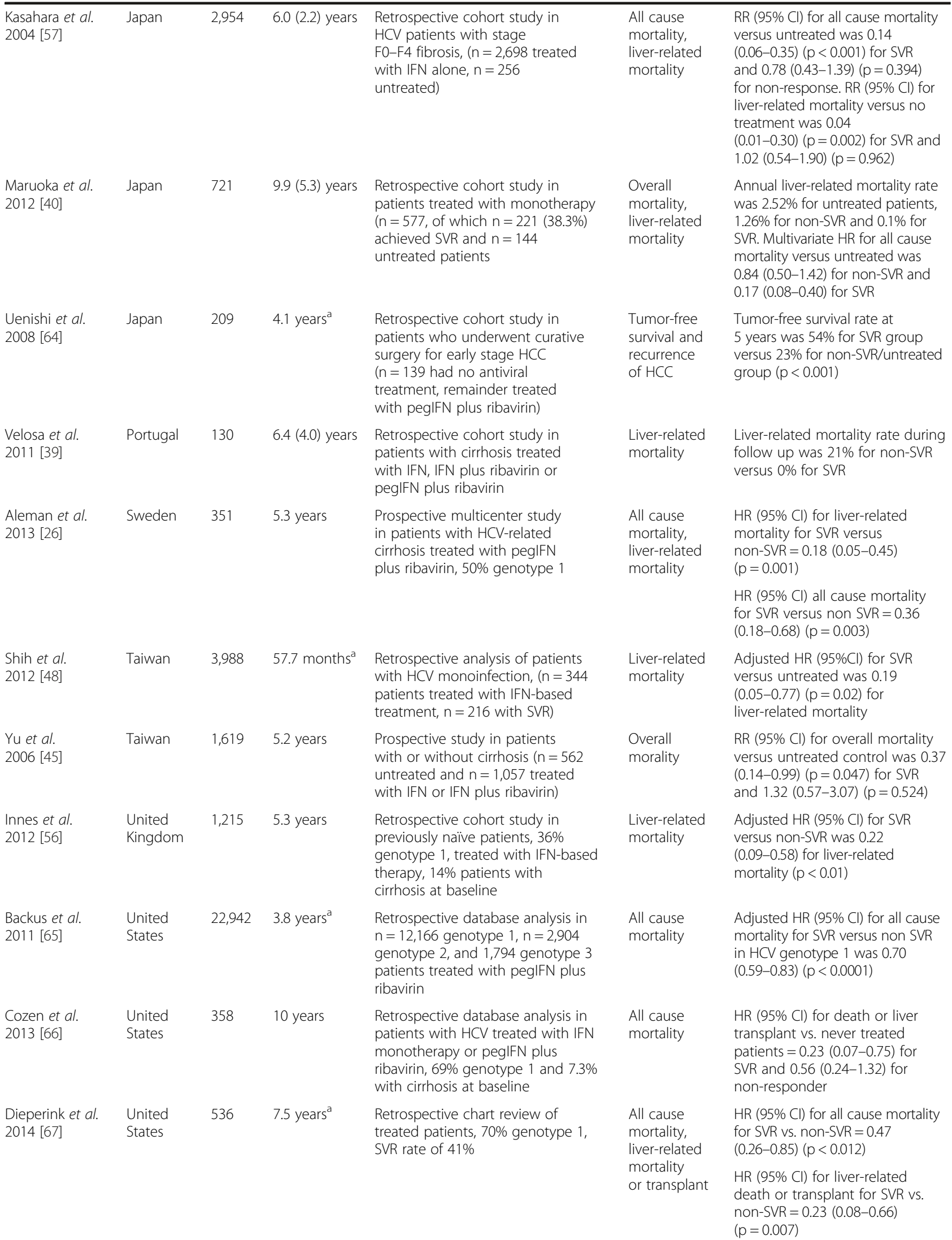


Table 3 Summary of clinical studies reporting the impact of SVR on all-cause and liver-related mortality (Continued)

\begin{tabular}{|c|c|c|c|c|c|c|}
\hline $\begin{array}{l}\text { Morgan et al. } \\
2010[41]\end{array}$ & $\begin{array}{l}\text { United } \\
\text { States }\end{array}$ & 140 & $\begin{array}{l}78.6(15.9) \\
\text { months }\end{array}$ & $\begin{array}{l}\text { Prospective analysis from the } \\
\text { HALT-C trial in patients with advanced } \\
\text { fibrosis treated with pegIFN plus } \\
\text { ribavirin and achieving SVR }\end{array}$ & $\begin{array}{l}\text { All cause } \\
\text { mortality, } \\
\text { liver-related } \\
\text { mortality, liver } \\
\text { transplantation }\end{array}$ & $\begin{array}{l}\text { HR }(95 \% \text { CI) for SVR versus non } \\
\text { response was } 0.17(0.06-0.46) \text { for } \\
\text { all cause mortality or transplant } \\
\text { and } 0.12(0.03-0.48) \text { for liver-related } \\
\text { mortality or transplant }\end{array}$ \\
\hline $\begin{array}{l}\text { Singal et al. } \\
2013[68]\end{array}$ & $\begin{array}{l}\text { United } \\
\text { States }\end{array}$ & 242 & 5 years & $\begin{array}{l}\text { Retrospective single center study in } \\
\text { patients treated with pegIFN plus } \\
\text { ribavirin, } 68 \% \text { genotype 1, } 31 \% \\
\text { with histological cirrhosis }\end{array}$ & $\begin{array}{l}\text { All cause } \\
\text { mortality }\end{array}$ & $\begin{array}{l}\text { HR for mortality for SVR versus } \\
\text { non-response }=0.11(0.03-0.47)\end{array}$ \\
\hline
\end{tabular}

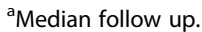

ALT, alanine aminotransferase; $\mathrm{Cl}$, confidence interval; HCC, hepatocellular carcinoma; HR, hazard ratio; IFN, interferon; ns, not significant; SVR, sustained virologic response.

Van der Meer showed that SVR led to a 3-fold reduction in the overall mortality rate $(1.01[0.46-1.56]$ per 100 patient years for SVR versus 2.93 [2.36-3.51] per 100 patient years for those without SVR; $\mathrm{p}<0.001$ ) and a 30-fold reduction in liver-related mortality or transplant $(0.23$ [0.01-0.50] per 100 patient years for SVR versus 3.20 [2.58-3.82] per 100 patient years for those without SVR; $\mathrm{p}<0.001)[38]$.

\section{Overall mortality}

Achievement of SVR has also been shown to reduce the risk of overall mortality (Table 3). For example, in a USbased study, SVR was associated with a HR (95\% CI) versus non SVR for all-cause mortality (for genotype 1 only) was $0.70(0.59-0.83)(\mathrm{p}<0.0001)$ [65]. Other studies report a much lower figure, with Morgan et al. reporting a HR $(95 \% \mathrm{CI})$ for all-cause mortality or liver transplant of $0.17(0.06-0.46)$ [41].

\section{Other complications}

Four studies identified in the review (conducted in Japan, Spain and the United States), showed that patients with SVR had a reduced risk for new onset diabetes in comparison with those not achieving SVR; in patients who achieved SVR the risk of developing diabetes was approximately 2-fold lower than for patients who failed treatment (Table 4). In all four studies investigating this associated the reduced risk for type 2 diabetes with SVR was statistically significant [69-72].

\section{Economic implications}

The incidence of late stage complications associated with HCV (e.g. HCC, decompensated cirrhosis and liver transplant) is a major contributor to the economic burden associated with HCV. In the US alone, direct annual costs associated with HCV exceed USD 1 billion [82], with annual per patient costs exceeding USD 50,000 for HCC and USD 110,000 for a single liver transplant [83]. Similarly, in Europe, a 5-country study by Vietri et al. showed that HCV patients have a high level of medical resource utilization leading to high direct costs as well as a high degree of absenteeism and presenteeism leading to high indirect costs. Indeed, Vietri et al. report direct annual costs of EUR 1,147 and indirect costs of EUR 7,533 per patient [84]. New antiviral treatment regimens that increase the SVR rate have the potential to influence future complication rates and therefore the overall economic burden; however, as triple therapy regimens are also associated with increased pharmacy costs in comparison with pegIFN plus ribavirin alone, costeffectiveness analyses are required in order to quantify the estimated long-term clinical and economic benefits. The initial literature review and update captured a total of five studies that specifically assessed the economic benefits of treatment in terms of cost per SVR achieved or cost of SVR versus failure (Table 5) [85-89].

One 2013 US-based study Manos et al. examined follow up costs for patients achieving SVR versus nonresponders over a 5-year period [89]. They report that patients with SVR (all genotypes) have mean annual costs (2007 USD) of USD 6,301 versus USD 10,149 for non-SVR patients, with the difference attributed to higher hospital costs (USD 5,167 versus USD 2,641) and outpatient costs (USD 4,983 versus USD 3,661). A similar UK-based analysis reported that costs in the 5 years post-treatment were 13-fold higher for patients who failed treatment versus those who achieved SVR, which increased to 56-fold for patients who initially failed treatment and were then retreated [85].

Three cost-effectiveness analyses presented results in terms of cost or incremental cost per SVR achieved [86-88]. In an Italian-based analysis Camma et al. reported an incremental cost per SVR achieved (versus pegIFN plus ribavirin) of EUR 60,500 per SVR for boceprevir IL28B guided therapy and EUR 74,600 per SVR for telaprevir IL28B guided therapy (2011 EUR) for treatment-naïve patients with $\mathrm{HCV}$ genotype 1 . However, a key limitation of this analysis is that US pharmacy costs were used as Italian costs were not available at the time of the analysis, which may have led to under- or over-estimation of the true cost-effectiveness [87]. Another analysis from the Greek setting showed that for the overall $\mathrm{HCV}$ genotype 1 population (including treatment naïve patients and prior non-responders and 
Table 4 Summary of clinical studies reporting the impact of SVR on liver-related complications

\begin{tabular}{|c|c|c|c|c|}
\hline Study & Setting & $\begin{array}{l}\text { Sample } \\
\text { size }\end{array}$ & $\begin{array}{l}\text { Mean } \\
\text { follow-up }\end{array}$ & Study details \\
\hline $\begin{array}{l}\text { Coverdale } \\
\text { et al. } 2004 \text { [47] }\end{array}$ & Australia & 455 & 9 years $^{a}$ & $\begin{array}{l}\text { Retrospective cohort study } \\
\text { including } 384 \text { treated with } \\
\text { IFN alone, ( } n=71 \text { untreated) } \\
\text { including patients with cirrhosis }\end{array}$ \\
\hline $\begin{array}{l}\text { Abergel et al. } \\
2004[73]\end{array}$ & France & 163 & Not stated & $\begin{array}{l}\text { Retrospective cohort study in } \\
\text { patients with severe fibrosis } \\
\text { treated with IFN alone }(n=64) \\
\text { or IFN plus ribavirin }(n=99)\end{array}$ \\
\hline $\begin{array}{l}\text { Braks et al. } \\
2007 \text { [43] }\end{array}$ & France & 113 & $\begin{array}{l}8.2(3.1) \\
\text { years }\end{array}$ & $\begin{array}{l}\text { Retrospective cohort study in } \\
\text { patients with compensated } \\
\text { cirrhosis treated with IFN, IFN } \\
\text { plus ribavirin or pegIFN } \\
\text { plus ribavirin }\end{array}$ \\
\hline $\begin{array}{l}\text { Poynard et al. } \\
2013[74]\end{array}$ & France & 933 & 6.3 years & $\begin{array}{l}\text { Prospective cohort study in } \\
\text { HCV patients, } 62 \% \text { genotype } 1\end{array}$ \\
\hline
\end{tabular}

Open label study in with liver

\begin{tabular}{|c|c|c|c|c|}
\hline $\begin{array}{l}\text { Wiese et al. } \\
2014 \text { [76] }\end{array}$ & Germany & 718 & 35 years & $\begin{array}{l}\text { Prospective, community-based } \\
\text { multicenter study in women } \\
\text { with HCV genotype 1, SVR } \\
\text { rate of } 46 \% \text { in treated patients }\end{array}$ \\
\hline $\begin{array}{l}\text { nnicchiarico } \\
\text { al. } 2012 \text { [77] }\end{array}$ & Italy & 135 & $\begin{array}{l}44.4 \\
\text { months }\end{array}$ & $\begin{array}{l}\text { Prospective study in } 135 \\
\text { HCV patients with cirrhosis }\end{array}$ \\
\hline
\end{tabular}

Bruno et al. Italy 218

2010 [78]

D’ambrosio et al. Italy

Arase et al.

Japan

2,842

2009 [69]

Imazeki et al.

Japan

459

2005 [46] transplant recipients treated with IFN plus ribavirin or pegIFN plus ribavirin,

$75 \%$ genotype 1

6.4 years $^{\mathrm{a}}$

\section{months}

months ${ }^{\mathrm{a}}$

11.4 years $^{\mathrm{a}}$

Retrospective cohort study in patients with compensated cirrhosis ( $n=149$ patients treated with IFN or IFN plus ribavirin),

but no esophageal varices

77 months Prospective cohort study in initially treatment-naïve patients with compensated cirrhosis, treated with IFN plus ribavirin

Retrospective cohort study in patients treated with IFN or pegIFN plus ribavirin, $6 \%$ patients had cirrhosis at baseline

Retrospective cohort study in patients, inc patients with cirrhosis, treated with IFN alone $(n=355)$ or untreated $(n=104)$, $\mathrm{n}=116$ patients achieved SVR

\section{Outcomes \\ Key findings}

assessed

Liver-related

complications

Progression

of fibrosis

Liver-related

complications

Regression

of fibrosis,

progression

to cirrhosis

Overall 9-year incidence liver-related

complication rate was $25 \%$ for untreated, 25\% for non-response and $2 \%$ for SVR

Fibrosis progression rate decreased in both responders and non-responders to treatment. 33\% SVR regressed from cirrhosis to severe fibrosis; corresponding figure for non-responders was $9 \%$ $(p=0.058)$

Proportion of patients with ascites was $5.4 \%$ for SVR vs. $10.5 \%$ for non-SVR, rates of digestive hemorrhage were $2.7 \%$ vs. $5.3 \%$, respectively

HR (95\% Cl) for regression of fibrosis at 10 years for SVR versus non-response $=$ $4.94(2.59-9.44)(p<0.001)$

HR $(95 \% \mathrm{Cl})$ for progression to cirrhosis $=0.185(0.106-0.264)$ for SVR and $0.173(0.123-0.224)$

Fibrosis stage $\quad$ For SVR mean (SD) necroinflammatory grade decreased from $1.9(0.6)$ to 1.0 (0.6) post-therapy and improved in $71.5 \%$ and remained stable in $26 \%$ SVR patients; corresponding figures in non-SVR patients were $51.5 \%$ and $46 \%$, respectively

Cirrhosis

Incidence of cirrhosis at 35 years post-infection $=6.0 \%$ for SVR vs. $15.3 \%$ for non-SVR

Portal hypertension

Development of portal hypertension was $10 \%$ for SVR versus $40 \%$ for non-SVR $(p<0.0005)$ progression of portal hypertension was $25 \%$ for SVR vs. $48 \%$ for non-SVR $(p<0.01)$

Esophageal Esophageal varices developed in varices 32\% untreated patients, 39\% non-SVR patients and 0\% SVR patients

Esophageal

varices (development of patients. 8-year cumulative probability and or progression of esophageal varices was $6 \%$ for in size/severity) SVR vs. $30 \%$ for non-SVR ( $p=0.03$ )

Onset of type

2 diabetes

Adjusted HR (95\% Cl) for the development of diabetes for non-SVR vs. SVR was $2.73(1.77-4.20)(p<0.001)$

Hepatic failure In the total population, annual incidence of hepatic failure was 0\% for SVR and $0.5 \%$ for non-responders; corresponding figures for patients with cirrhosis were $0 \%$ and $1.0 \%$, respectively 
Table 4 Summary of clinical studies reporting the impact of SVR on liver-related complications (Continued)

\begin{tabular}{|c|c|c|c|c|c|c|}
\hline $\begin{array}{l}\text { Uenishi et al. } \\
2008 \text { [64] }\end{array}$ & Japan & 209 & 4.1 years $^{a}$ & $\begin{array}{l}\text { Retrospective cohort study } \\
\text { in patients who underwent } \\
\text { curative surgery for early stage } \\
\text { HCC ( } n=139 \text { had no antiviral } \\
\text { treatment, remainder treated } \\
\text { with pegIFN plus ribavirin) }\end{array}$ & $\begin{array}{l}\text { Tumor-free } \\
\text { survival and } \\
\text { recurrence } \\
\text { of HCC }\end{array}$ & $\begin{array}{l}\text { Tumor-free survival rate at } 5 \text { years } \\
\text { was } 54 \% \text { for SVR group vs. } 23 \% \text { for } \\
\text { non-SVR/untreated group ( } p<0.001 \text { ) }\end{array}$ \\
\hline $\begin{array}{l}\text { Lee et al. } \\
2013 \text { [80] }\end{array}$ & $\begin{array}{l}\text { South } \\
\text { Korea }\end{array}$ & 315 & $\begin{array}{l}45 \\
\text { months }\end{array}$ & $\begin{array}{l}\text { Retrospective chart review, } \\
86 \% \text { patients treated, 15\% with } \\
\text { cirrhosis at baseline, SVR } \\
\text { rate of } 75 \%\end{array}$ & Cirrhosis & $\begin{array}{l}\text { Cumulative } 5 \text { year rate of cirrhosis } \\
\text { was } 27.6 \% \text { for patients without SVR } \\
\text { vs. } 0 \% \text { for patients with SVR }(p<0.01)\end{array}$ \\
\hline $\begin{array}{l}\text { Canete et al. } \\
2013 \text { [81] }\end{array}$ & Spain & 105 & 9.3 years & $\begin{array}{l}\text { Retrospective study of paired } \\
\text { biopsy data in HCV patients } \\
\text { with mild-moderate fibrosis } \\
\text { treated with IFN plus ribavirin }\end{array}$ & $\begin{array}{l}\text { Progression } \\
\text { of fibrosis }\end{array}$ & $\begin{array}{l}\text { Progression of fibrosis was reported } \\
\text { in } 5.3 \% \text { patients with SVR and } 50 \% \\
\text { patients with non-response ( } p<0.0001) \text {. } \\
\text { Fibrosis improved in } 30.5 \% \text { patients } \\
\text { with SVR and } 14.6 \% \text { patients with } \\
\text { non-response }\end{array}$ \\
\hline $\begin{array}{l}\text { Simo et al. } \\
2006 \text { [70] }\end{array}$ & Spain & 234 & 5.7 years & $\begin{array}{l}\text { Retrospective cohort study in } \\
\text { patients with HCV (without } \\
\text { severe fibrosis) treated with } \\
\text { IFN or IFN plus ribavirin, } \\
79 \% \text { genotype } 1\end{array}$ & $\begin{array}{l}\text { Onset of type } \\
2 \text { diabetes }\end{array}$ & $\begin{array}{l}\text { HR }(95 \% \mathrm{Cl}) \text { for onset of diabetes for } \\
\text { SVR vs. non-SVR was } 0.48(0.24-0.98) \\
(p=0.04)\end{array}$ \\
\hline $\begin{array}{l}\text { Aleman et al. } \\
2013 \text { [26] }\end{array}$ & Sweden & 351 & 5.3 years & $\begin{array}{l}\text { Prospective multicenter study } \\
\text { in patients with HCV-related } \\
\text { cirrhosis treated with pegIFN } \\
\text { plus ribavirin, } 50 \% \text { genotype } 1\end{array}$ & $\begin{array}{l}\text { Decompensated } \\
\text { cirrhosis (ascites, } \\
\text { variceal bleeding, } \\
\text { encephalopathy) }\end{array}$ & $\begin{array}{l}\text { HR }(95 \% \mathrm{Cl}) \text { for hepatic } \\
\text { decompensation for SVR vs. non } \\
\text { SVR }=0.23(0.08-0.53)(p=0.002)\end{array}$ \\
\hline $\begin{array}{l}\text { Innes et al. } \\
2012 \text { [56] }\end{array}$ & $\begin{array}{l}\text { United } \\
\text { Kingdom }\end{array}$ & 1,215 & 5.3 years & $\begin{array}{l}\text { Retrospective cohort study in } \\
\text { previously naïve patients, } 36 \% \\
\text { genotype 1, treated with } \\
\text { IFN-based therapy, } 14 \% \text { patients } \\
\text { with cirrhosis at baseline }\end{array}$ & $\begin{array}{l}\text { Liver-related } \\
\text { inpatient } \\
\text { hospital } \\
\text { episodes }\end{array}$ & $\begin{array}{l}\text { Adjusted HRs }(95 \% \mathrm{Cl}) \text { for SVR } \\
\text { versus non-SVR were } 0.22(0.15-0.34) \\
\text { for liver-related hospital episode } \\
(p<0.01)\end{array}$ \\
\hline $\begin{array}{l}\text { Cozen et al. } \\
2013 \text { [66] }\end{array}$ & $\begin{array}{l}\text { United } \\
\text { States }\end{array}$ & 358 & 10 years & $\begin{array}{l}\text { Retrospective database analysis } \\
\text { in patients with HCV treated } \\
\text { with IFN monotherapy or pegIFN } \\
\text { plus ribavirin, 69\% genotype } 1 \\
\text { and } 7.3 \% \text { with cirrhosis at } \\
\text { baseline }\end{array}$ & Cirrhosis & $\begin{array}{l}\text { HR }(95 \% \mathrm{Cl}) \text { for development of } \\
\text { cirrhosis vs. never treated }=0.68 \\
(0.26-1.80) \text { for SVR and } 2.35 \\
(1.18-4.69) \text { for non-responders }\end{array}$ \\
\hline $\begin{array}{l}\text { Hyder et al. } \\
2013 \text { [72] }\end{array}$ & $\begin{array}{l}\text { United } \\
\text { States }\end{array}$ & 20,486 & 5 years & $\begin{array}{l}\text { Retrospective database analysis } \\
\text { of US veterans with no history } \\
\text { of diabetes treated between } \\
\text { 1998-2007 }\end{array}$ & $\begin{array}{l}\text { Onset of type } \\
2 \text { diabetes }\end{array}$ & $\begin{array}{l}\text { HR }(95 \% \mathrm{Cl}) \text { for onset of type } 2 \\
\text { diabetes for SVR versus non-response } \\
\text { was } 0.76(0.70-0.82)(p<0.0001)\end{array}$ \\
\hline $\begin{array}{l}\text { Oni et al. } \\
2011 \text { [71] }\end{array}$ & $\begin{array}{l}\text { United } \\
\text { States }\end{array}$ & 8,687 & $>6$ years & $\begin{array}{l}\text { Retrospective database analysis } \\
\text { in patients treated with } \\
\text { peglFN-based treatment }\end{array}$ & $\begin{array}{l}\text { Onset of type } \\
2 \text { diabetes }\end{array}$ & $\begin{array}{l}\text { Rate of new onset of diabetes was } \\
10.2 \% \text { for SVR group vs. } 15 \% \text { for } \\
\text { non-SVR group }\end{array}$ \\
\hline
\end{tabular}

${ }^{a}$ Median follow up.

ALT, alanine aminotransferase; Cl, confidence interval; HCC, hepatocellular carcinoma; HR, hazard ratio; IFN, interferon; ns = not significant; SVR, sustained virologic response.

relapsers), that telaprevir-based triple therapy was dominant to pegIFN plus ribavirin in terms of cost per SVR gained (telaprevir was associated with a cost-saving of EUR 10,403 per SVR gained) [88].

\section{Quality of life}

The literature review process identified a total of 15 studies that examined HRQoL in patients with SVR [17,90-103], and a further study was identified via searches of the bibliographic sections of included studies [18]. The most commonly used instrument in HRQoL studies was the SF-36, and studies that used this almost universally showed that patients with SVR had better scores than non-responder/relapser/untreated populations, both in terms of sub-domains and physical and mental component summary scores, with a large proportion of between group differences achieving statistical significance. On an individual domain level, in studies that used the SF-36, the largest differences between patients with SVR and those without were reported for general health followed by role physical $[18,103]$.

A total of seven studies (including two costeffectiveness analyses of triple therapy), reported utility values for SVR using a number of different methods including standard gamble, time trade off (TTO) and the Health Utilities Index Mark 3 (HUI3) (Table 6). In one 
Table 5 Summary of literature relating to the health economic implications of SVR

\begin{tabular}{lll}
\hline Study (setting) & Patients & Interventions \\
\hline $\begin{array}{l}\text { Morais et al. } \\
2013 \text { (Brazil) [86] }\end{array}$ & $\begin{array}{l}\text { Treatment-naïve patients with } \\
\text { genotype 1 with F2 fibrosis } \\
\text { in Brazil }\end{array}$ & $\begin{array}{l}\text { Boceprevir plus PR and } \\
\text { telaprevir plus PR }\end{array}$ \\
& & \\
Backx et al. & Treated genotype 1 patients & $\begin{array}{l}\text { Patients treated with PR for } \\
\text { a minimum of 2 months }\end{array}$
\end{tabular}

Camma et al. 2012 (Italy) [87]

Yfantopoulos et al. 2012 (Greece) [88]

Treatment-naïve and treatmentexperienced HCV genotype 1 aged 50 years with $\mathrm{F} 2$ fibrosis
Treatment-naïve HCV genotype 1,

Boceprevir- or telaprevir based triple therapy (including RGT) versus pegIFN plus ribavirin alone, time horizon of 20 years

Telaprevir-based triple therapy versus boceprevir-based triple therapy

PegIFN plus ribavirin

Chronic HCV patients treated from 2002-2007, excluding pre- and post-liver transplant antiviral treatment

\section{Key findings}

In the public health system cost per SVR was BRL 50,751 for telaprevir plus PR and BRL 63,481 for boceprevir plus PR. In the private health system cost per SVR was BRL 88,508 for telaprevir plus PR and BRL 82,518 for boceprevir plus PR

For non-cirrhotic patients 5-year post-treatment costs were 13-fold higher for non SVR patients vs. SVR (GBP 2,530 versus GBP 190), and 56-fold higher for non-SVR patients who were retreated (GBP 10,722)

ICER per SVR versus pegIFN plus ribavirin was EUR 56,960-85,650 for boceprevir and EUR 74,600-118,000 for telaprevir

In total population, mean cost per SVR was EUR 46,635 for telaprevir and EUR 56,146 for boceprevir. For treatment-naïve population cost per SVR was EUR 38,868 and EUR 42,983, respectively. For treatment-experienced patients cost per SVR was EUR 48,966 and EUR 59,902 respectively. Telaprevir was dominant to boceprevir

Manos et al. 2013 (United States) [89]
In the 5 years following treatment mean yearly total (hospital and outpatient) costs in genotype 1 patients were USD 2,504 higher for non-responders than for patients with SVR $(p=0.042)$

HCC, hepatocellular carcinoma; ICER, incremental cost-effectiveness ratio; RGT, response-guided therapy; SVR, sustained virologic response.

Table 6 Health state utilities for HCV patients achieving SVR

\begin{tabular}{|c|c|c|c|c|}
\hline \multirow[t]{2}{*}{ Method } & \multirow[t]{2}{*}{ Study } & \multicolumn{2}{|l|}{ Value } & \multirow[t]{2}{*}{ Difference } \\
\hline & & SVR & Non-response/relapse & \\
\hline \multirow[t]{3}{*}{ EQ5D } & Thein et al. 2005 [93] & 0.83 & - & - \\
\hline & Chong et al. 2003 [95] & 0.83 & $0.76^{c}$ & 0.07 \\
\hline & Van Rooijen et al. 2011 [99] & 0.84 & 0.70 & 0.14 \\
\hline SF-36 & Thein et al. 2005 [93] & $0.74-0.90$ & $0.70-0.86^{b}$ & $0.04-0.05$ \\
\hline \multirow[t]{2}{*}{ SF-6D } & Hsu et al. 2012 [103] & 0.71 & $0.66^{c}$ & 0.05 \\
\hline & John-Baptiste et al. 2009 [18] & 0.71 & 0.65 & 0.06 \\
\hline \multirow[t]{3}{*}{ HUI3 } & Thein et al. 2005 [93] & 0.77 & - & - \\
\hline & John-Baptiste et al. 2009 [18] & 0.70 & 0.58 & 0.12 \\
\hline & Hsu et al. 2012 [103] & 0.70 & $0.57^{c}$ & 0.13 \\
\hline HUI & Chong et al. 2003 [95] & 0.77 & $0.73^{c}$ & 0.04 \\
\hline \multirow[t]{2}{*}{ ТTO } & John-Baptiste et al. 2009 [18] & 0.89 & 0.84 & 0.05 \\
\hline & Hsu et al. 2012 [103] & 0.88 & $0.80^{c}$ & 0.08 \\
\hline \multirow[t]{2}{*}{ SG } & Thein et al. 2005 [93] & 0.86 & - & - \\
\hline & Chong et al. 2003 [95] & 0.86 & $0.79^{c}$ & 0.08 \\
\hline \multirow[t]{2}{*}{ VAS } & Thein et al. 2005 [93] & 0.74 & - & - \\
\hline & Chong et al. 2003 [95] & 0.74 & $0.70^{c}$ & 0.04 \\
\hline \multirow[t]{2}{*}{ Not stated } & Liu et al. 2012 [104] & $0.933-1.00^{a}$ & - & - \\
\hline & Chhatwal et al. 2013 [105] & 1.00 & - & - \\
\hline
\end{tabular}

HUI3, Health Utilities Index Mark 3; SF-36, Medical Outcomes Study 36-item Short-Form Health Survey; SG, standard gamble; TTO, time trade off; VAS, visual analog scale.

${ }^{a}$ Age-specific quality of life weight.

bUntreated.

${ }^{\mathrm{C}}$ Patients with mild/moderate HCV or chronic infection. 
cost-effectiveness analysis by Liu et al. the mean utility value associated with SVR was dependent upon whether the subject had mild fibrosis or cirrhosis [104]. Previous studies have shown that HRQoL is influenced by disease severity, but the study by Liu et al. is one of the few studies to suggest the quality of life benefit of SVR is influenced by baseline disease severity. Utility values associated with the SVR state were strongly influenced by the method of assessment used and were typically highest using the TTO (ranging from 0.88-0.89) and standard gamble methods (0.86) (Table 6) and lowest using the SF-6D (0.71) and visual analog scale methods (0.74). Additionally, assessment of utility values using the EQ$5 \mathrm{D}$ valuation index led to values of $0.83-0.84$ for SVR in comparison with $0.70-0.76$ for non-response/relapse (Table 6) $[95,99]$.

Most quality of life studies included in the review assessed HRQoL within the first year following treatment; however two studies assessed the impact of SVR at $>3$ years after completion of antiviral therapy. Both Mauss et al. [17] and John-Baptiste et al. [18] reported that the HRQoL benefits of SVR persist over $>3$ years, with both studies showing that patients with SVR had significantly better scores in all eight domains of the SF36 in comparison with those who had failed treatment. Both Mauss et al. [17] and John-Baptiste et al. [18] also showed that SVR was associated with long-term benefits in terms of work productivity. Mauss et al. reported that a significantly higher proportion of patients who achieved SVR were employed $(56 \%)$ in comparison with non-SVR patients (41\%; $\mathrm{p}<0.0001)$ [17]. Similarly, John-Baptiste et al. reported employment figures of $67 \%$ for patients with SVR versus $51 \%$ for those who failed treatment $(\mathrm{p}=0.02)$. This analysis also showed that long-term work and leisure capacity were significantly compromised in treatment failures in comparison with the SVR group. Treatment failures had a mean (SD) reduction in work capacity of 5.8 (18)\%, versus 1.1 (6)\% for SVR; the corresponding figures for reduction in leisure capacity were $10.7(24) \%$ and 3.3 (13\%), respectively [18].

\section{Discussion}

The overarching aim of the present review was to consolidate published findings relating to the clinical, economic and quality of life benefits associated with achieving SVR and draw together these data to assess how clinical and quality of life benefits translate into economic benefits on both a per-patient and system-wide level. Previous research has largely focused on individual clinical, economic or quality of life aspects of SVR and has not examined how these benefits overlap and interact within a larger framework. For example, on an individual patient level, attainment of SVR is associated with lower risk of progression, HCC and liver-related mortality, less time spent in hospitals and improved symptoms and quality of life. However, when scaled up to a system wide level, SVR translates into substantial direct cost-savings for the payer due to costly complications avoided, as well as lower indirect costs due to lost productivity through absenteeism and presenteeism.

SVR is widely regarded as a cure and has been shown to be durable with rates of late relapse being in the region of $1-2 \%$. In addition to halting progression of liver damage, SVR-induced regression of fibrosis and even cirrhosis has been reported. For example in a meta-analysis of 8 European studies, Veldt et al. reported regression of fibrosis in approximately one third of patients achieving SVR [106]. Additionally, risk factors such as heavy alcohol use or co-infection with hepatitis B may lead to progression of liver disease even in the presence of SVR. The clinical implications of potential low level viral persistence are not well characterized and it remains largely unknown whether it influences post-SVR progression of liver disease.

There is extensive evidence relating to the clinical benefits of SVR. A reduced risk for progression to cirrhosis, HCC, liver transplantation and liver-related mortality is evident regardless of setting, age, HCV subtype or level of fibrosis (Tables 2, 3, 4 and 7). However, the magnitude of the impact of SVR in terms of its impact on mortality rates varied notably between studies identified in this review, with some studies suggesting that following SVR the risk for liver-related mortality is comparable to that of the general population, whilst others suggest that mortality risk, although lower than for treatment failures, remains elevated in comparison with the general population. A contributing factor in this disparity may be heterogeneity in populations studied. Some studies excluded patients with advanced fibrosis or cirrhosis, whilst others were conducted exclusively in cirrhotic patients; there were also differences between patient populations in terms of age, previous treatment history, and the relative prevalence of different HCV genotypes.

The absolute risk and the magnitude of benefit does appear to be highly dependent on age and pre-treatment level of fibrosis. One study by Yoshida et al. [36] in the Japanese setting assessed the gain in HCC-free survival (defined as the difference in expected HCC-free survival with SVR versus without) according to age and fibrosis level. They report that the gain in HCC-free survival was greater when the subject was younger and had advanced fibrosis at baseline. For example for patients with stage F2 fibrosis the RR $(95 \% \mathrm{CI})$ for HCC were $1.76(0.47-$ 6.67) for SVR versus 2.86 (1.59-5.13) for non-SVR, whereas for patients with F4 fibrosis the RRs (95\% CI) increase to 4.78 (1.13-20.18) and 12.23 (6.81-21.95), respectively. A large proportion of the HCC studies identified in the current review $(n=11 / 24)$ were conducted in 
Table 7 Meta-analyses of long-term clinical outcomes in patients with SVR

\begin{tabular}{|c|c|c|c|}
\hline Study & Details & Outcomes assessed & Key findings \\
\hline $\begin{array}{l}\text { Almasio et al. } \\
2003[107]\end{array}$ & $\begin{array}{l}\text { Systematic review and pooled analysis } \\
(\mathrm{N}=1,031 \text { patients for cirrhosis analysis, } \\
\mathrm{N}=3,914 \text { patients for } \mathrm{HCC} \text { analysis })\end{array}$ & HCC, progression to cirrhosis & $\begin{array}{l}\text { Risk reduction for progression to cirrhosis for } \\
\text { SVR versus no SVR }=-0.22(-0.36 \text { to }-0.08) \text {. Risk } \\
\text { reduction for } H C C=-0.097(-0.13 \text { to }-0.07)\end{array}$ \\
\hline $\begin{array}{l}\text { Kimer et al. } \\
2012[51]\end{array}$ & $\begin{array}{l}\text { Systematic review and meta-analysis of } 8 \\
\text { RCTs and } 5 \text { prospective studies ( } N=3,208 \text { patients); } \\
\text { random effects model used. Patients treated } \\
\text { with IFN, pegIFN or PegIFN plus ribavirin }\end{array}$ & $\mathrm{HCC}$ & $\begin{array}{l}\text { RR (95\% for HCC for SVR versus no } \\
\text { intervention }=0.15(0.05-0.45)\end{array}$ \\
\hline \multirow[t]{3}{*}{$\begin{array}{l}\text { Morgan et al. } \\
2013 \text { [53] }\end{array}$} & \multirow{3}{*}{$\begin{array}{l}\text { Systematic review and meta-analysis of } \\
30 \text { studies ( } N=31,528 \text { patients) } \\
\text { (18 studies included in meta-analysis) investigating } \\
\text { impact of treatment on risk for HCC }\end{array}$} & \multirow[t]{3}{*}{$\mathrm{HCC}$} & \multirow{2}{*}{$\begin{array}{l}\text { For patients at all stages of disease } \\
\text { HR }(95 \% \mathrm{Cl}) \text { for HCC for SVR versus } \\
\text { non-response }=0.24(0.18-0.31) \\
(p<0.001)\end{array}$} \\
\hline & & & \\
\hline & & & $\begin{array}{l}\text { For patients with advanced liver disease } \\
\text { HR }(95 \% \mathrm{Cl}) \text { for HCC for SVR versus } \\
\text { non-response }=0.23(0.16-0.35)(p<0.001)\end{array}$ \\
\hline $\begin{array}{l}\text { Singal et al. } \\
2010[49]\end{array}$ & $\begin{array}{l}\text { Systematic review and meta-analysis of } \\
20 \text { studies ( } N=4,700 \text { patients) in treatment-naïve } \\
\text { patients treated with IFN or IFN plus ribavirin; } \\
\text { random effects model used }\end{array}$ & $\mathrm{HCC}$ & $\begin{array}{l}\text { RR }(95 \% \mathrm{Cl}) \text { for HCC for SVR versus } \\
\text { non-responders }=0.35(0.26-0.46)\end{array}$ \\
\hline \multirow[t]{2}{*}{$\begin{array}{l}\text { Singal et al. } \\
2010[50]\end{array}$} & \multirow[t]{2}{*}{$\begin{array}{l}\text { Systematic review and meta-analysis of } 26 \\
\text { studies ( } N=13,191 \text { patients) }\end{array}$} & \multirow[t]{2}{*}{$\begin{array}{l}\text { HCC, hepatic decompensation, } \\
\text { liver-related mortality }\end{array}$} & $\begin{array}{l}\text { RR }(95 \% \mathrm{Cl}) \text { for SVR versus treatment failure } \\
\text { were: HCC } 0.21(0.16-0.27)(p=n s) \\
\text { for all patients and } 0.27(0.19-0.39) \\
\text { ( } p=n s) \text { for patients with cirrhosis. }\end{array}$ \\
\hline & & & $\begin{array}{l}\text { Liver-related mortality was } 0.23(0.10-0.52) \\
(p=n s) \text { for all patients and } 0.13(0.06-0.29) \\
(p=n s) \text { for patients with cirrhosis. RR }(95 \% \mathrm{Cl}) \\
\text { Hepatic decompensation } 0.16(0.04-0.59) \\
(p=n s) \text { for all patients and } 0.08(0.03-0.21) \\
(p=0.02) \text { for patients with cirrhosis }\end{array}$ \\
\hline
\end{tabular}

$\mathrm{Cl}$, confidence interval; $\mathrm{HCC}$, hepatocellular carcinoma; $\mathrm{RCT}$, randomized controlled trial; $\mathrm{RR}$, relative risk.

the Japanese setting, which has among the highest incidence of HCV-related HCC in the world, with an estimated 30,000 deaths per year attributable to HCC [36] and a mean annual treatment cost of USD 42,360 in Japan (2010 USD) [16]. As such, even a modest reduction in HCC, such as 100 cases avoided per year, would lead to savings of over USD 4 million for the payer.

The underlying reason for the high HCC rate in Japan is thought to be partly due to the high relative prevalence of genotype $1 \mathrm{~b}$ (which is associated with a higher risk for HCC development in comparison with other genotypes [108]) relative to the US and Europe, and also to the fact that the spread of HCV is thought to have begun earlier in Japan than in Europe and North America, [109] therefore leading to an older prevalent population, with more advanced disease and therefore higher risk for developing HCC.

The clinical benefits of SVR are not limited to HCC. Patients with SVR have reduced risk of progression, liver-related mortality, liver transplantation and overall mortality in comparison with those not achieving SVR. Liver transplantation has a mean (global) cost of USD 146,960 in the year of transplant [16], so again even small reductions in the number of liver transplants required translate into substantial savings for the payer. The risk of overall mortality is reduced by approximately 5 -fold, and liver related mortality approximately 10 -fold, versus nonSVR, although this is influenced by age and level of fibrosis prior to treatment.

Patients with HCV have been shown to be at elevated risk for co-morbid conditions including type 2 diabetes [110]. Three studies showed that patients with SVR had a lower incidence of new onset diabetes versus nonresponders. The mechanism for this is not clear, although hypotheses include elevated insulin resistance caused by pro-inflammatory cytokines [71]. It is has also proposed that insulin resistance may influence the likelihood of achieving SVR, rather than SVR influencing diabetogenic processes [111]. HCV is associated with a number of other extra-hepatic complications, although there are a lack of data on the impact of SVR on these.

The clinical benefits associated with SVR due to complications avoided translate into economic benefits from a third party perspective. The magnitude of economic benefit is difficult to quantify, due to uncertainty of prevalence estimates and continued advances in therapy leading to ongoing improvements in SVR rates but owing to the high cost, even a small reduction in the incidence of HCC would have considerable economic implications. In addition to direct costs, the attainment of SVR also has implications on indirect costs such as lost productivity, with evidence to suggest that employment rates 
are higher amongst patients with SVR versus those without $[17,18]$.

The clinical benefits associated with the achievement of SVR translate into clinically meaningful benefits for patients by improving symptoms, functioning and health related quality of life, compared with those not able to achieve SVR. The findings of quality of life studies consistently showed that patients with SVR had higher utility values and SF-36 and EQ-5D scores in comparison with those who did not respond to treatment. However, in the literature review it was noted that there is a paucity of quality of life studies with long-term follow-up ( $\geq 5$ years). Although SVR leads to improved quality of life in the short-term, data relating to whether or not this improvement persists in the long term are lacking.

Although the scope of the present review was such that the endpoints of fatigue and depression were not assessed directly, SVR is also associated with other benefits in terms of patient reported outcomes including fatigue and depression, which are common side effects associated with antiviral treatment. The Fatigue Severity Scale (FSS) is a commonly used instrument to assess fatigue in $\mathrm{HCV}$ studies. The FSS has good reliability, validity and responsiveness and a total score $\geq 4$ is indicative of severe fatigue. In addition to improved SVR, protease inhibitors are associated with benefits in terms of reduced fatigue. Published data relating to the magnitude of change in FSS score required to constitute a minimally important difference are lacking. However, analysis of phase III simeprevir trial data indicate that a clinically meaningful change (improvement or worsening) may be as small as $0.33-0.34$ and that patients with SVR have significant improvements in FSS score versus non-responders (Janssen, data on file).

The current study has several limitations that should be acknowledged with regard to interpretation of the findings. In particular, the review included studies that compare SVR groups with both untreated groups and nonresponder groups. Several studies in Japan have shown that risk of HCC and overall mortality are reduced, although not significantly in patients who receive treatment but fail to achieve SVR in comparison with untreated patients, although the mechanism behind this is poorly understood $[57,112]$. Moreover, in a considerable proportion of the studies reported here no distinction is made by the authors in the non-SVR groups in terms of null-response, partial response or relapse following treatment. The potential benefits of SVR in relapsers is an area that warrants further investigation as two studies included here suggested that patients who relapse have lower risks for overall mortality and HCC in comparison with true non-responders [37]. Similarly, whether benefits of SVR are different across different sub-populations, such as patients with hepatitis B or HIV coinfection, or is influenced by genotype, is an issue for future analysis. A further limitation of the current review is that no formal quality assessment of included studies was performed.

While this systematic literature review attempted to be as holistic as possible in capturing the impact of achieving SVR in patients chronically infected with hepatitis C, it was not possible to capture all possible consequences. For example, the benefits associated with reduced infection risk were not considered, and therefore represent a limitation of the review. Additionally, during the literature search it was noted that an aspect of $\mathrm{HCV}$ that is often overlooked in the literature is the stigma associated with $\mathrm{HCV}$ and the impact of this on patients' quality of life, disclosure practices and treatment-seeking behavior. Stigma may be subtle and is inherently difficult to quantify. One of the key factors in stigma arises due to fear of transmission, which although limited to blood-borne routes, does not prevent stigma. Patients with SVR are no longer at risk of transmitting HCV to others, therefore the stigma associated with HCV should be removed. Another aspect to consider is the public health benefit associated with a lower population prevalence; a reduced population prevalence means that there are fewer people from whom $\mathrm{HCV}$ can be transmitted to others.

\section{Conclusions}

In conclusion, review of the literature has shown that achievement of SVR in patients with chronic HCV infection is associated with significant clinical, economic and quality of life benefits. Patients who achieve SVR, including those with advanced disease, have a substantially reduced risk of progression to cirrhosis, development of HCC and both liver-related and all cause mortality. This reduced risk of late stage complications also leads to economic benefits. Post-treatment, patients with SVR also have lower healthcare resource utilization versus non-responders, which also translates into substantial economic benefits from a healthcare payer perspective. Finally, the attainment of SVR is also associated with improved quality of life.

\section{Additional file}

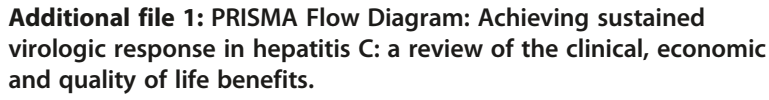

Additional file 1: PRISMA Flow Diagram: Achieving sustained virologic response in hepatitis C: a review of the clinical, economic and quality of life benefits.

\section{Competing interests}

This manuscript was funded by Janssen Pharmaceutica NV JSP and WV are current employees of Ossian Health Economics and Communications, which has received consulting fees from Janssen Pharmaceutica NV. KC is a current employee of Janssen Pharmaceutica NV.

\section{Authors' contributions}

JSP performed data acquisition and analysis and prepared first and subsequent drafts of the manuscript. KC was involved in the conception and design of the review, contributed to first and subsequent drafts of the manuscript and was involved in the critical review of all drafts of the manuscript. WV contributed to data acquisition and analysis and was 
involved in the critical review of all drafts of the manuscript. All authors read and approved the final manuscript.

\section{Grant support}

This study was supported by funding from Janssen Pharmaceutica NV.

\section{Author details}

Ossian Health Economics and Communications, Ossian Health Economics and Communications GmbH, Bäumleingasse 20, 4051 Basel, Switzerland.

${ }^{2}$ Janssen Pharmaceutica NV, Beerse, Belgium.

Received: 19 August 2014 Accepted: 7 January 2015

Published online: 17 January 2015

\section{References}

1. Mohd Hanafiah K, Groeger J, Flaxman AD, Wiersma ST. Global epidemiology of hepatitis C virus infection: new estimates of age-specific antibody to HCV seroprevalence. Hepatology. 2013;57:1333-42.

2. Parkin DM. The global health burden of infection-associated cancers in the year 2002. Int J Cancer. 2006;1 18:3030-44.

3. Jacobson IM, Poordad F, Brown Jr RS, Kwo PY, Reddy KR, Schiff E. Standardization of terminology of virological response in the treatment of chronic hepatitis C: panel recommendations. J Viral Hepat. 2012;19:236-43.

4. Wedemeyer H, Jensen DM, Godofsky E, Mani N, Pawlotsky JM, Miller V, et al. Recommendations for standardized nomenclature and definitions of viral response in trials of hepatitis $C$ virus investigational agents. Hepatology. 2012;56:2398-403.

5. Jacobson IM, Dore GJ, Foster GR, Fried MW, Radu M, Rafalsky W, et al. Simeprevir with pegylated interferon alfa 2a plus ribavirin in treatment-naive patients with chronic hepatitis C virus genotype 1 infection (QUEST-1): a phase 3, randomised, double-blind, placebo-controlled trial. Lancet. 2014 S0140-6736(14):60494-3.

6. Manns M, Marcellin P, Poordad F, de Araujo ES, Buti M, Horsmans Y, et al. Simeprevir with pegylated interferon alfa $2 \mathrm{a}$ or $2 \mathrm{~b}$ plus ribavirin in treatment-naive patients with chronic hepatitis C virus genotype 1 infection (QUEST-2): a randomised, double-blind, placebo-controlled phase 3 trial. Lancet. 2014;S0140-6736(14):60538-9.

7. Kowdley KV, Lawitz E, Crespo I, Hassanein T, Davis MN, DeMicco M, et al. Sofosbuvir with pegylated interferon alfa-2a and ribavirin for treatment-naive patients with hepatitis C genotype-1 infection (ATOMIC): an open-label, randomised, multicentre phase 2 trial. Lancet. 2013;381:2100-7.

8. Lawitz E, Mangia A, Wyles D, Rodriguez-Torres M, Hassanein T, Gordon SC, et al. Sofosbuvir for previously untreated chronic hepatitis $C$ infection. N Engl J Med. 2013;368:1878-87.

9. Afdhal N, Zeuzem S, Kwo P, Chojkier M, Gitlin N, Puoti M, et al. ION-1 Investigators. Ledipasvir and sofosbuvir for untreated HCV genotype 1 infection. N Engl J Med. 2014;370:1889-98.

10. Afdhal N, Reddy KR, Nelson DR, Lawitz E, Gordon SC, Schiff E, et al. ION-2 Investigators. Ledipasvir and sofosbuvir for previously treated HCV genotype 1 infection. N Engl J Med. 2014;370:1483-93.

11. Pearlman BL, Traub N. Sustained virologic response to antiviral therapy for chronic hepatitis C virus infection: a cure and so much more. Clin Infect Dis. 2011;52:889-900

12. Swain MG, Lai MY, Shiffman ML, Cooksley WG, Zeuzem S, Dieterich DT, et al. A sustained virologic response is durable in patients with chronic hepatitis $\mathrm{C}$ treated with peginterferon alfa-2a and ribavirin. Gastroenterology. 2010;139:1593-601

13. Martinot-Peignoux M, Stern C, Maylin S, Ripault MP, Boyer N, Leclere L, et al. Twelve weeks posttreatment follow-up is as relevant as 24 weeks to determine the sustained virologic response in patients with hepatitis $C$ virus receiving pegylated interferon and ribavirin. Hepatology. 2010;51:1122-6.

14. Campos-Varela I, Castells L, Esteban Jl, Bes M, Rodríguez-Frías F, Sapisochin G, et al. Twelve-week posttreatment follow-up to predict sustained virologic response for recurrent hepatitis $C$ infection in liver recipients. Transplantation. 2012;93:450-3.

15. Chen J, Florian J, Carter W, Fleischer RD, Hammerstrom TS, Jadhav PR, et al. Earlier sustained virologic response end points for regulatory approval and dose selection of hepatitis C therapies. Gastroenterology. 2013;144:1450-5.

16. El Khoury AC, Wallace C, Klimack WK, Razavi H. Economic burden of hepatitis C-associated diseases: Europe, Asia Pacific, and the Americas. J Med Econ. 2012;15:887-96.
17. Mauss S, Petersen J, Witthoeft T, Busch HW, Christensen S, Zehnter E, et al. Sustained Responders have Lower Rates of Liver-Related Events and a Better Quality of Life and Productivity Compared with Non-Responders/Relapsers after Antiviral Treatment of Chronic Hepatitis C [abstract] Hepatology. 63rd Annual Meeting of the American Association for the Study of Liver Diseases: The Liver Meeting 2012 Boston, MA United States. 9-13 November 2012 pp 5

18. John-Baptiste AA, Tomlinson G, Hsu PC, Krajden M, Heathcote EJ, Laporte A, et al. Sustained responders have better quality of life and productivity compared with treatment failures long after antiviral therapy for hepatitis C. Am J Gastroenterol. 2009;104:2439-48.

19. Deuffic-Burban S, Mathurin P, Pol S, Larsen C, Roudot-Thoraval F, Desenclos JC, et al. Impact of hepatitis $C$ triple therapy availability upon the number of patients to be treated and associated costs in France: a model-based analysis. Gut. 2012;61:290-6.

20. Van Der Meer AJP, Veldt BJ, Feld JJ, Wedemeyer H, Dufour J-F, Lammert F, et al. Improvement of interferon-based therapy substantially reduced the number needed to treat to prevent HCC among HCV genotype 1 infected cirrhotics [abstract]. Amsterdam, Netherlands: 48th Annual Meeting of the European Association for the Study of the Liver; 2013.

21. Wang C-H, Chang K-K, Lin R-C, Kuo J-J. Insights into hepatocellular carcinoma occurrence and long-term outcomes in patients with chronic hepatitis C infection after successful antiviral treatment [abstract]. Singapore: 23rd Conference of the Asian Pacific Association for the Study of the Liver; 2013.

22. Sasaki R, Abiru S, Yamasaki K, Komori A, Yatsuhashi H. Risk factors for hepatocellular carcinoma developed after sustained virological response in hepatitis C patients [abstract]. Brisbane, Australia: Abstract presented at the 23rd Conference of the Asian Pacific Association for the Study of the Liver; 2014.

23. Calvaruso V, Bavetta MG, Ferraro D, Grimaudo S, Conte E, Pipitone RM, et al. Risk of disease decompensation and HCC in patients with HCV cirrhosis non responders to PEG IFN plus RBV [abstract]. Bologna, Italy: 19th National Congress of Digestive Diseases, Italian Federation of Societies of Digestive Diseases; 2013.

24. Hara T, Fukushima T, Kawamura Y, Sezaki H, Hosaka T, Akuta N, et al. Sustained viral response reduces liver complications and total mortality among Japanese elderly with hepatitis C virus infection [abstract]. Brisbane, Australia: 23rd Conference of the Asian Pacific Association for the Study of the Liver; 2014.

25. Ogawa E, Furusyo N, Kajiwara E, Takahashi K, Nomura H, Maruyama T, et al. Efficacy of pegylated interferon alpha- $2 b$ and ribavirin treatment on the risk of hepatocellular carcinoma in patients with chronic hepatitis $\mathrm{C}$ : a prospective, multicenter study. J Hepatol. 2013;58:495-501.

26. Aleman S, Rahbin N, Weiland O, Davidsdottir L, Hedenstierna M, Rose N, et al. A risk for hepatocellular carcinoma persists long-term after sustained virologic response in patients with hepatitis C-associated liver cirrhosis. Clin Infect Dis. 2013;57:230-6.

27. Pellicelli AM, Vignally P, Romano M, Miglioresi L, Mazzoni E, Mecenate F, et al. Impact of liver fibrosis in development of hepatocellular carcinoma in genotype 1 chronic hepatitis C patients treated with antiviral therapy: Long term follow up study [abstract]. 48th Annual Meeting of the European Association for the Study of the Liver, International Liver Congress 2013 Amsterdam Netherlands. 24-28 April 2013

28. Imai Y, Tamura S, Tanaka H, Hiramatsu N, Kiso S, Doi Y, et al. Reduced risk of hepatocellular carcinoma after interferon therapy in aged patients with chronic hepatitis $C$ is limited to sustained virological responders. J Viral Hepat. 2010;17:185-91.

29. Kobayashi S, Takeda T, Enomoto M, Tamori A, Kawada N, Habu D, et al. Development of hepatocellular carcinoma in patients with chronic hepatitis C who had a sustained virological response to interferon therapy: a multicenter, retrospective cohort study of 1124 patients. Liver Int. 2007;27:186-91.

30. Hung CH, Lee CM, Lu SN, Wang JH, Hu TH, Tung HD, et al. Long-term effect of interferon alpha-2b plus ribavirin therapy on incidence of hepatocellular carcinoma in patients with hepatitis $C$ virus-related cirrhosis. J Viral Hepat. 2006;13:409-14.

31. Moriyama M, Matsumura H, Aoki H, Shimizu T, Yamagami H, Shioda A, et al. Decreased risk of hepatocellular carcinoma in patients with chronic hepatitis $C$ whose serum alanine aminotransferase levels became less than twice the upper limit of normal following interferon therapy. Liver Int. 2005;25:85-90. 
32. Watanabe S, Enomoto N, Koike K, Izumi N, Takikawa H, Hashimoto E, et al. Cancer preventive effect of pegylated interferon $a-2 b$ plus ribavirin in a real-life clinical setting in Japan: PERFECT interim analysis. Hepatol Res. 2011;41:955-64.

33. Wang CH, Mo LR, Chang KK, Lin RC, Kuo JJ. A cohort study to investigate hepatocellular carcinoma risk in hepatitis $\mathrm{C}$ patients. Hepatogastroenterology. 2011;58:904-8.

34. Sasaki M, Yoshida K, Yoshimatsu S, Setoyama H, Chiyonaga S, Narita R, et al. Hepatocarcinogenesis after SVR by interferon therapy in chronic hepatitis C patients [abstract]. Journal of Gastroenterology and Hepatology. Asian Pacific Digestive Week 2011 Singapore. 1-4 October 2011 pp 169

35. Ikeda K, Arase Y, Saitoh S, Kobayashi M, Someya T, Hosaka T, et al. Anticarcinogenic impact of interferon on patients with chronic hepatitis C: a large-scale long-term study in a single center. Intervirology. 2006;49:82-90.

36. Yoshida H, Tateishi R, Arakawa Y, Sata M, Fujiyama S, Nishiguchi S, et al. Benefit of interferon therapy in hepatocellular carcinoma prevention for individual patients with chronic hepatitis C. Gut. 2004;53:425-30.

37. Ogawa E, Furusyo N, Kajiwara E, Takahashi K, Nomura H, Tanabe Y, et al. Complete Hepatitis $C$ virus elimination during pegylated interferon a2B and ribavirin treatment reduces the risk of progression to hepatocellular carcinoma [abstract]. Journal of Hepatology. 47th Annual Meeting of the European Association for the Study of the Liver, International Liver Congress 2012 Barcelona Spain. 18-22 April 2012

38. van der Meer AJ, Veldt BJ, Feld JJ, Wedemeyer H, Dufour JF, Lammert F, et al. Association between sustained virological response and all-cause mortality among patients with chronic hepatitis $C$ and advanced hepatic fibrosis. JAMA. 2012:308:2584-93.

39. Velosa J, Serejo F, Marinho R, Nunes J, Glória H. Eradication of hepatitis C virus reduces the risk of hepatocellular carcinoma in patients with compensated cirrhosis. Dig Dis Sci. 2011;56:1853-61.

40. Maruoka D, Imazeki F, Arai M, Kanda T, Fujiwara K, Yokosuka O. Long-term cohort study of chronic hepatitis $C$ according to interferon efficacy. J Gastroenterol Hepatol. 2012;27:291-9.

41. Morgan TR, Ghany MG, Kim HY, Snow KK, Shiffman ML, De Santo JL, et al. Outcome of sustained virological responders with histologically advanced chronic hepatitis C. Hepatology. 2010;52:833-44.

42. Cardoso AC, Moucari R, Figueiredo-Mendes C, Ripault MP, Giuily N, Castelnau $\mathrm{C}$, et al. Impact of peginterferon and ribavirin therapy on hepatocellular carcinoma: incidence and survival in hepatitis $C$ patients with advanced fibrosis. J Hepatol. 2010;52:652-7.

43. Braks RE, Ganne-Carrie N, Fontaine H, Paries J, Grando-Lemaire V, Beaugrand $M$, et al. Effect of sustained virological response on long-term clinical outcome in 113 patients with compensated hepatitis C-related cirrhosis treated by interferon alpha and ribavirin. World J Gastroenterol. 2007;13:5648-53.

44. Bruno S, Stroffolini T, Colombo M, Bollani S, Benvegnù L, Mazzella G, et al. Sustained virological response to interferon-alpha is associated with improved outcome in HCV-related cirrhosis: a retrospective study. Hepatology. 2007:45:579-87

45. Yu ML, Lin SM, Chuang WL, Dai CY, Wang JH, Lu SN, et al. A sustained virological response to interferon or interferon/ribavirin reduces hepatocellular carcinoma and improves survival in chronic hepatitis C: a nationwide, multicentre study in Taiwan. Antivir Ther. 2006:11:985-94.

46. Imazeki F, Yokosuka O, Fukai K, Kawai S, Kanda T, Kojima H, et al. Lower incidence of hepatic failure than hepatocellular carcinoma in Japanese patients with chronic hepatitis C. Liver Int. 2005:25:772-8.

47. Coverdale SA, Khan MH, Byth K, Lin R, Weltman M, George J, et al. Effects of interferon treatment response on liver complications of chronic hepatitis C: 9-year follow-up study. Am J Gastroenterol. 2004;99:636-44.

48. Shih K, Su W-W, Hsu Y-C, Yen H-H, Wu S-S, Soon M-S Interferon-based treatment reduced hepatocellular carcinoma development and liver related death incidence in chronic hepatitis $C$ patients $V$ Single institution experience [abstract]. Hepatology International. 22nd Conference of the Asian Pacific Association for the Study of the Liver, APASL 2012 Taipei Taiwan (Republic of China). 16-19 February 2012

49. Singal AK, Singh A, Jaganmohan S, Guturu P, Mummadi R, Kuo YF, et al. Antiviral therapy reduces risk of hepatocellular carcinoma in patients with hepatitis C virus-related cirrhosis. Clin Gastroenterol Hepatol. 2010;8:192-9.

50. Singal AG, Volk ML, Jensen D, Di Bisceglie AM, Schoenfeld PS. A sustained viral response is associated with reduced liver-related morbidity and mortality in patients with hepatitis C virus. Clin Gastroenterol Hepatol. 2010;8:280-8.
51. Kimer N, Dahl EK, Gluud LL, Krag A. Antiviral therapy for prevention of hepatocellular carcinoma in chronic hepatitis C: systematic review and meta-analysis of randomised controlled trials. BMJ Open. 2012;2(5):1-7.

52. $\mathrm{Ng} \mathrm{V}$, Saab S. Effects of a sustained virologic response on outcomes of patients with chronic hepatitis C. Clin Gastroenterol Hepatol. 2011;9:923-30.

53. Morgan RL, Baack B, Smith BD, Yartel A, Pitasi M, Falck-Ytter Y. Eradication of hepatitis $C$ virus infection and the development of hepatocellular carcinoma: a meta-analysis of observational studies. Ann Intern Med. 2013;158:329-37.

54. Lauer GM, Walker BD. Hepatitis C virus infection. N Engl J Med. 2001;345:41-52.

55. Namiki I, Nishiguchi S, Hino K, Suzuki F, Kumada H, Itoh $Y$, et al. Management of hepatitis C; Report of the Consensus Meeting at the 45th Annual Meeting of the Japan Society of Hepatology (2009). Hepatol Res. 2010:40:347-68.

56. Innes HA, Hutchinson SJ, Allen S, Bhattacharyya D, Bramley P, Delahooke TE, et al. Excess liver-related morbidity of chronic hepatitis $C$ patients, who achieve a sustained viral response, and are discharged from care. Hepatology. 2011;54:1547-58

57. Kasahara A, Tanaka H, Okanoue T, Imai Y, Tsubouchi H, Yoshioka K, et al. Interferon treatment improves survival in chronic hepatitis $\mathrm{C}$ patients showing biochemical as well as virological responses by preventing liver-related death. J Viral Hepat. 2004;11:148-56.

58. Imazeki F, Yokosuka O, Fukai K, Saisho H. Favorable prognosis of chronic hepatitis $C$ after interferon therapy by long-term cohort study. Hepatology. 2003;38:493-502

59. Selzner N, Renner EL, Selzner M, Adeyi O, Kashfi A, Therapondos G, et al. Antiviral treatment of recurrent hepatitis $C$ after liver transplantation: predictors of response and long-term outcome. Transplantation. 2009;88:1214-21.

60. Tanaka T, Selzner N, Therapondos G, Renner EL, Lilly LB. Virological response for recurrent hepatitis $C$ improves long-term survival in liver transplant recipients. Transpl Int. 2013;26:42-9.

61. Van Der Meer AJ, Veldt BJ, Feld JJ, Wedemeyer H, Dufour J-F, Lammert F, et al. Sustained virological response improves overall survival in chronic hepatitis $C$ patients with advanced fibrosis [abstract]. Hepatology. 63rd Annual Meeting of the American Association for the Study of Liver Diseases: The Liver Meeting 2012 Boston, MA United States. 9-13 November 2012

62. Aguilera V, Garcia M, Rubin A, Navarro L, Prieto M, Berenguer M. Improved outcome after anti-hcv therapy is less marked when therapy is started at advanced stages of fibrosis [abstract]. Journal of Hepatology. 47th Annual Meeting of the European Association for the Study of the Liver, International Liver Congress 2012 Barcelona Spain. 18-22 April 2012

63. Kutala BK, Duval X, Guedj J, Asselah T, Marcellin P. Impact of antiviral therapy on survival in patients with advanced fibrosis - Experience of Beaujon Hospital 2000 to 2010 [abstract]. Amsterdam, Netherlands: 48th Annual Meeting of the European Association for the Study of the Liver; 2013.

64. Uenishi T, Nishiguchi S, Tanaka S, Yamamoto T, Takemura S, Kubo S. Response to interferon therapy affects risk factors for postoperative recurrence of hepatitis C virus-related hepatocellular carcinoma. J Surg Oncol. 2008;98:358-62

65. Backus LI, Boothroyd DB, Phillips BR, Belperio P, Halloran J, Mole LA. A sustained virologic response reduces risk of all-cause mortality in patients with hepatitis C. Clin Gastroenterol Hepatol. 2011;9:509-16.

66. Cozen ML, Ryan JC, Shen H, Lerrigo R, Yee RM, Sheen E, et al. Nonresponse to interferon-a based treatment for chronic hepatitis $C$ infection is associated with increased hazard of cirrhosis. PLoS One. 2013;8:e61568

67. Dieperink E, Pocha C, Thuras P, Knott A, Colton S, Ho SB. All-cause mortality and liver-related outcomes following successful antiviral treatment for chronic hepatitis C. Dig Dis Sci. 2014;59:872-80.

68. Singal AG, Dharia TD, Malet PF, Alqahtani S, Zhang S, Cuthbert JA. Long-term benefit of hepatitis $C$ therapy in a safety net hospital system: a cross-sectional study with median 5-year follow-up. BMJ Open 2013;3(9):e003231.

69. Arase $Y$, Suzuki F, Suzuki $Y$, Akuta N, Kobayashi M, Kawamura $Y$, et al. Sustained virological response reduces incidence of onset of type 2 diabetes in chronic hepatitis C. Hepatology. 2009;49:739-44.

70. Simó R, Lecube A, Genescà J, Esteban Jl, Hernández C. Sustained virological response correlates with reduction in the incidence of glucose abnormalities in patients with chronic hepatitis $C$ virus infection. Diabetes Care. 2006:29:2462-6. 
71. Oni OA, Rao G, Pandya PK. Impact of sustained virologic response on incident diabetes in chronic hepatitis C [abstract] Hepatology. 62nd Annual Meeting of the American Association for the Study of Liver Diseases: The Liver Meeting 2011 San Francisco, CA United States. 4-8 November 2011

72. Hyder SM, Krishnan S, Promrat K. Sustained virological response prevents the development of new type 2 diabetes in patients with chronic hepatitis C [abstract]. Gastroenterology. 2013;144(5 Suppl 1):S951. Conference: Digestive Disease Week 2013, DDW 2013 Orlando, FL United States. 18-21 May 2013.

73. Abergel A, Darcha C, Chevallier M, Ughetto S, Henquell C, Pol S, et al. Histological response in patients treated by interferon plus ribavirin for hepatitis C virus-related severe fibrosis. Eur J Gastroenterol Hepatol. 2004;16:1219-27.

74. Poynard T, Moussalli J, Munteanu M, Thabut D, Lebray P, Rudler M, et al. Slow regression of liver fibrosis presumed by repeated biomarkers after virological cure in patients with chronic hepatitis C. J Hepatol. 2013;59:675-83.

75. Roche B, Sebagh M, Canfora ML, Antonini T, Roque-Afonso AM, Delvart V, et al. Hepatitis $C$ virus therapy in liver transplant recipients: response predictors, effect on fibrosis progression, and importance of the initial stage of fibrosis. Liver Transpl. 2008;14:1766-77.

76. Wiese M, Fischer J, Löbermann M, Göbel U, Grüngreiff K, Güthoff W, et al. Evaluation of liver disease progression in the German hepatitis $C$ virus (1b)-contaminated anti-D cohort at 35 years after infection. Hepatology. 2014:59:49-57.

77. Annicchiarico BE, Siciliano M, Santonocito C, Zocco MA, Avolio AW, Barbaro F. Long-term outcome of hepatitis C-related liver cirrhosis at different stages of portal hypertension after sustained virological response [abstract] Hepatology. 63rd Annual Meeting of the American Association for the Study of Liver Diseases: The Liver Meeting 2012 Boston, MA United States. 9-13 November 2012

78. Bruno S, Crosignani A, Facciotto C, Rossi S, Roffi L, Redaelli A, et al. Sustained virologic response prevents the development of esophageal varices in compensated, Child-Pugh class A hepatitis C virus-induced cirrhosis. A 12-year prospective follow-up study. Hepatology. 2010;51:2069-76.

79. D'Ambrosio R, Aghemo A, Rumi MG, Primignani M, Dell'Era A, Lampertico P, et al. The course of esophageal varices in patients with hepatitis $C$ cirrhosis responding to interferon/ribavirin therapy. Antivir Ther. 2011;16:677-84.

80. Lee SJ, Yeon JE, Lee HJ, Yoon EL, Suh SJ, Kim JH, et al. Risk of cirrhosis and hepatocellular carcinoma in chronic hepatitis $C_{\text {; }}$ long term outcome and prognostic factors [abstract]. Singapore: 23rd conference of the Asian Pacific Association for the Study of the Liver; 2013.

81. Canete N, Garcia M, Ojanguren I, Cirera I, Garcia-Retortillo M, Carrion JA, et al. Long-term evolution of liver fibrosis in mild-moderate chronic hepatitis C: Study with paired biopsies [abstract]. Journal of Hepatology. 48th Annual Meeting of the European Association for the Study of the Liver, International Liver Congress 2013 Amsterdam Netherlands. 18-24 April 2013

82. Basseri B, Yamini D, Chee G, Enayati PD, Tran T, Poordad F. Comorbidities associated with the increasing burden of hepatitis $C$ infection. Liver Int. 2010:30:1012-8.

83. McAdam-Marx C, McGarry LJ, Hane CA, Biskupiak J, Deniz B, Brixner DI. All-cause and incremental per patient per year cost associated with chronic hepatitis C virus and associated liver complications in the United States: a managed care perspective. J Manag Care Pharm. 2011;17:531-46.

84. Vietri J, Prajapati G, El Khoury AC. The burden of hepatitis C in Europe from the patients' perspective: a survey in 5 countries. BMC Gastroenterol. 2013;13:16.

85. Backx M, Lewszuk A, White JR, Cole J, Sreedharan A, van Sanden S, et al. The cost of treatment failure: resource use and costs incurred by hepatitis $C$ virus genotype 1-infected patients who do or do not achieve sustained virological response to therapy. J Viral Hepat. 2014;21:208-15.

86. Morais AD, Pereira ML. Cost per cure of telaprevir and boceprevir in treatment-naive genotype 1 hepatitis c patients with F2 fibrosis in Brazil [abstract]. Dublin, Ireland: ISPOR 16th Annual European Congress; 2013.

87. Cammà C, Petta S, Enea M, Bruno R, Bronte F, Capursi V, et al. Cost-effectiveness of boceprevir or telaprevir for untreated patients with genotype 1 chronic hepatitis C. Hepatology. 2012;56:850-60.

88. Yfantopoulos J, Paparouni K, D'Angelo ER. A cost-effectiveness analysis of telaprevir versus boceprevir in the treatment of hepatitis C: A greek national health system perspective [abstract]. Berlin Germany: ISPOR 15th Annual European Congress; 2012. p. A394.

89. Manos MM, Darbinian J, Rubin J, Ray GT, Shvachko V, Denis B, et al. The effect of hepatitis $C$ treatment response on medical costs: a longitudinal analysis in an integrated care setting. J Manag Care Pharm. 2013;19:438-47.

90. Bini EJ, Mehandru S. Sustained virological response rates and health-related quality of life after interferon and ribavirin therapy in patients with chronic hepatitis $C$ virus infection and persistently normal alanine aminotransferase levels. Aliment Pharmacol Ther. 2006;23:777-85.

91. Arora S, O'Brien C, Zeuzem S, Shiffman ML, Diago M, Tran A, et al. Treatment of chronic hepatitis $C$ patients with persistently normal alanine aminotransferase levels with the combination of peginterferon alpha-2a $(40 \mathrm{kDa})$ plus ribavirin: impact on health-related quality of life. J Gastroenterol Hepatol. 2006;21:406-12.

92. Spiegel BM, Younossi ZM, Hays RD, Revicki D, Robbins S, Kanwal F. Impact of hepatitis $C$ on health related quality of life: a systematic review and quantitative assessment. Hepatology. 2005;41:790-800.

93. Thein $\mathrm{HH}$, Krahn M, Kaldor JM, Dore GJ. Estimation of utilities for chronic hepatitis C from SF-36 scores. Am J Gastroenterol. 2005;100:643-51.

94. Hassanein T, Cooksley G, Sulkowski M, Smith C, Marinos G, Lai MY, et al. The impact of peginterferon alfa-2a plus ribavirin combination therapy on health-related quality of life in chronic hepatitis C. J Hepatol. 2004;40:675-81.

95. Chong CA, Gulamhussein A, Heathcote EJ, Lilly L, Sherman M, Naglie G, et al. Health-state utilities and quality of life in hepatitis $C$ patients. Am J Gastroenterol. 2003:98:630-8.

96. Bonkovsky HL, Snow KK, Malet PF, Back-Madruga C, Fontana RJ, Sterling RK et al. Health-related quality of life in patients with chronic hepatitis $C$ and advanced fibrosis. J Hepatol. 2007:46:420-31.

97. Mathew A, Peiffer LP, Rhoades K, McGarrity TJ. Improvement in quality of life measures in patients with refractory hepatitis $C$, responding to re-treatment with Pegylated interferon alpha $-2 b$ and ribavirin. Health Qual Life Outcomes. 2006;4:30.

98. Hollander A, Foster GR, Weiland O. Health-related quality of life before, during and after combination therapy with interferon and ribavirin in unselected Swedish patients with chronic hepatitis C. Scand J Gastroenterol. 2006:41:577-85.

99. Van Rooijen EM, Hotho D, Agthoven M, Van Der Kolk A, Hansen BE, Knegt R, Uyl-De Groot CA. The cost and quality of life of hepatitis $C$ in the Netherlands [abstract]. Value in Health. ISPOR 14th Annual European Congress Madrid Spain. 5-8 November 2011. pp A394

100. Papastergiou V, Skorda L, Lisgos P, Hletsos M, Ketikoglou I, Zamanis C, Karatapanis S. Health-related quality of life in patients with chronic hepatitis C. The impact of antiviral therapy. European Journal of Internal Medicine. 10th Congress of the European Federation of Internal Medicine Athens Greece. 5-8 November 2011 pp S46

101. Björnsson E, Verbaan H, Oksanen A, Frydén A, Johansson J, Friberg S, et al. Health-related quality of life in patients with different stages of liver disease induced by hepatitis C. Scand J Gastroenterol. 2009;44:878-87.

102. Younossi Z, Aggarwal J, Martin M, Hernandez N, Donepudi M, Bayliss M, et al. Health-related quality-of-life among genotype 1 treatment-naive chronic Hepatitis C patients receiving telaprevir combination treatment: Post-hoc analyses of data from the advance trial [abstract]. Journal of Hepatology. 47th Annual Meeting of the European Association for the Study of the Liver, International Liver Congress 2012 Barcelona Spain. 18-22 April 2012

103. Hsu PC, Federico CA, Krajden M, Yoshida EM, Bremner KE, Anderson FH, et al. Health utilities and psychometric quality of life in patients with early- and late-stage hepatitis C virus infection. J Gastroenterol Hepatol. 2012;27:149-57.

104. Liu S, Cipriano LE, Holodniy M, Owens DK, Goldhaber-Fiebert JD. New protease inhibitors for the treatment of chronic hepatitis $C:$ a cost-effectiveness analysis. Ann Intern Med. 2012;156:279-90.

105. Chhatwal J, Ferrante SA, Brass C, El Khoury AC, Burroughs M, Bacon B, et al. Cost-effectiveness of boceprevir in patients previously treated for chronic hepatitis C genotype 1 infection in the United States. Value Health. 2013;16:973-86.

106. Veldt BJ, Saracco G, Boyer N, Cammà C, Bellobuono A, Hopf U, et al. Long term clinical outcome of chronic hepatitis $C$ patients with sustained virological response to interferon monotherapy. Gut. 2004;53:1504-8. 
107. Almasio PL, Venezia G, Craxi A. The impact of antiviral therapy on the course of chronic HCV infection. A systematic review. Panminerva Med. 2003:45:175-82.

108. Raimondi S, Bruno S, Mondelli MU, Maisonneuve P. Hepatitis C virus genotype $1 \mathrm{~b}$ as a risk factor for hepatocellular carcinoma development: a meta-analysis. J Hepatol. 2009;50:1142-54.

109. Tanaka Y, Hanada K, Orito E, Akahane Y, Chayama K, Yoshizawa H, et al. Molecular evolutionary analyses implicate injection treatment for schistosomiasis in the initial hepatitis C epidemics in Japan. J Hepatol. 2005:42:47-53.

110. Mehta SH, Brancati FL, Sulkowski MS, Strathdee SA, Szklo M, Thomas DL. Prevalence of type 2 diabetes mellitus among persons with hepatitis $C$ virus infection in the United States. Ann Intern Med. 2000;133(8):592-9.

111. Romero-Gómez M, Del Mar VM, Andrade RJ, Salmerón J, Diago M, Fernández-Rodríguez $\mathrm{CM}$, et al. Insulin resistance impairs sustained response rate to peginterferon plus ribavirin in chronic hepatitis $C$ patients. Gastroenterology. 2005;128:636-41.

112. Shiratori Y, Ito Y, Yokosuka O, Imazeki F, Nakata R, Tanaka N, et al. Antiviral therapy for cirrhotic hepatitis C: association with reduced hepatocellular carcinoma development and improved survival. Ann Intern Med. 2005:142:105-14.

\section{Submit your next manuscript to BioMed Central and take full advantage of:}

- Convenient online submission

- Thorough peer review

- No space constraints or color figure charges

- Immediate publication on acceptance

- Inclusion in PubMed, CAS, Scopus and Google Scholar

- Research which is freely available for redistribution 